\title{
2017 Sosyal Bilgiler Dersi Öğretim Programı Beceri ve Değerlerinin Anahtar Yetkinlikler Açısından Analizi
}

\section{Analysis of the Skills and Values of the 2017 Social Studies Curriculum in Terms of Key Competencies}

\section{Berna OTUZ*}

\author{
Büşra GÖRKAŞ-KAYABAŞI**
}

\section{Gülay EKİCi $* * *$}

\begin{abstract}
Received: 26 March 2018
Research Article

Accepted: 12 September 2018

ABSTRACT: This study was prepared for two purposes. In this scope; 1 . Analyzing the key competences of Turkey Qualifications Framework (TQF) in terms of skills, attitudes and values 2. Comparing the contents of "Basic Skills in Curriculum" and "Teaching Values in Curriculum" of the 2017 Social Studies Curriculum (SSC) and the contents of key competency areas in the TQF are aimed in this study. Qualitative research model was used in case study. With the documents used for putting forward the skills, attitudes and values contained in the key competence areas and the dimensions of "Basic Skills" and "Teaching Values" were examined through content analysis. Based on the analysis results, SSC's "Basic Skills" and "Teaching Values" dimensions were compared with the contents of key competency areas included in TQF. It has been determined that "Mathematical Competence and Basic Competencies in Science Technology" are included most in the "Basic Skills in Curriculum" dimension. It has been determined that healthy life, leadership, artistic expression and creativity skills are not included in the curriculum. It has been concluded that the missing skills shall be included among the SSC skills and the contents of key competencies in TQF should be changed to include the values that are expected from individuals.
\end{abstract}

Keywords: key competencies, social studies curriculum.

ÖZ: Bu çalışmada 2017 Sosyal Bilgiler Dersi Öğretim Programı (SBDÖP)'nın TYÇ'de yer alan anahtar yetkinliklerle ilişkisini ortaya koymak amaçlanmaktadır. Bu doğrultuda; 1. TYÇ'deki anahtar yetkinlik alanlarının; içerdiği beceri ve değerler açısından analiz edilmesi 2. 2017 Sosyal Bilgiler Dersi Öğretim Programı (SBDÖP)'nın “Öğretim Programında Temel Beceriler” ve “Öğretim Programında Değerler Eğitimi” boyutlarının içeriği ile TYÇ’de yer alan anahtar yetkinlik alanlarının içeriğinin karşılaştırılması şeklinde iki alt amaç belirlenmiştir. Araştırmada nitel araştırma modeli kapsamında durum çalışması deseni kullanılmıştır. Anahtar yetkinlik alanlarının analizinde yararlanılan dokümanlar ile öğretim programının "Temel Beceriler" ve "Değerler Eğitimi” boyutları içerik analizi yoluyla incelenmiştir. Analiz sonuçlarına dayalı olarak 2017 SBDÖP'nın "Temel Beceriler" ve "Değerler Eğitimi" boyutları ile anahtar yetkinlik alanlarının içeriği karşılaştırılmıştır. Araştırma sonuçlarına göre; öğretim programının beceri boyutunda en fazla "Matematiksel Yetkinlik ve Bilim Teknolojide Temel Yetkinlikler" e yer verildiği, sağlıklı yaşam, liderlik, sanatsal ifade ve yaratıcılık becerilerinin programında yer almadığ1 tespit edilmiştir. Eksik bulunan becerilere SBDÖP becerileri arasında yer verilmesi ve TYÇ'de yer alan anahtar yetkinliklerin bireylerden beklediğimiz değerleri de içerecek biçimde düzenlenmesi gerektiği sonucuna ulaşılmıştır.

Anahtar kelimeler: anahtar yetkinlikler, sosyal bilgiler dersi öğretim programı.

* Corresponding Author: PhD Student, Gazi University, Ankara, Turkey, bernaserdar@ gmail.com

Res. Asst., Gazi University, Ankara, Turkey, busragorkas@gmail.com

Prof. Dr., Gazi University, Ankara, Turkey, gulayekici@ yahoo.com

\section{Citation Information}

Otuz, B., Kayabaşı, G. B., \& Ekici, G. (2018). 2017 Sosyal bilgiler dersi öğretim programının beceri ve değerlerinin anahtar yetkinlikler açısından analizi. Kuramsal Eğitimbilim Dergisi [Journal of Theoretical Educational Science], 11(4), 944-972. 


\section{Giriş}

21. yüzyılda ekonomilerin hızla değişen taleplerine ve işgücü gereksinimlerine ayak uydurabilmek için, bireylere kazandırılması hedeflenen beceriler ve yeterlilikler üzerinde yeniden düşünmek gerekmektedir. Son yıllarda tüm dünyada eğitim alanında en çok tartışılan, üzerinde araştırmalar yapılan konulardan biri de 21 . yüzyıl becerileri ve bu becerilerin eğitim yoluyla kazandırılmasıdır.

Dünyada birçok kurum ve kuruluş gelecekte bireylerde bulunması gereken 21 . yüzyıl becerilerinin neler olabileceği konusunda yaptıkları araştırmaların sonuçlarını paylaşmaktadır (American Assosciation of School Administrators [AASA], 1996; Assessment and Teaching of 21st Century Skills [ATCS], 2007; Association of American Colleges and Universities [AACU], 2016; European Parliament and the Council of the European Union [EU], 2006; Internetional Society for Technology in Education, [ISTE], 2016; National Council on Measurement in Education [NCME], 2016; Organization for Economic Cooperation and Development [OECD], 2009; Partnership for 21st Century Skills [P21], 2006) World Economic Forum [WEF], 2015). Yukarıda belirtilen tüm kurumların ve bu kurumların hazırladıkları çalışmaların temel amac1, 21.yüzyıl becerilerine sahip nesillerin hangi kriterlere göre yetiştirilebileceğinin belirlenmesidir. İletişim, iş birliğii, eleştirel düşünme, bilgi okuryazarlığ 1 , karar alma, esneklik ve uyum, küresel vatandaşlık ve dijital okuryazarlık belirtilen kaynaklarda s1klıkla vurgulanan beceriler arasında yer almaktadır.

21. yüzyılın gereklerine sahip bireyler yetiştirmek için eğitim sistemlerindeki yeni anlayış, yönelim ve gelişmeler küresel anlamda tüm ülkeleri etkilemektedir (Erginer, 2006). Ulusal Eğitim Birliği, eğitim programları birimi (CSCENPA, 2007), 21.yüzyılın eğitim programının temel çerçevesini, toplumun ekonomik, sosyal ve inanç sistemlerini geliştiren faktörlerle ilgili bir farkındalık kazandırma, bireyi gerekli kişisel nitelik ve becerilerle donatma ve böylelikle gittikçe küreselleşen ve farklılıkların ortaya çıktığ1 dünyada donanımlı, sorumluluk almaya istekli, bütüncül bir bakış açısı ve dünya görüşüne sahip bireyler yetiştirme olarak belirlemiştir (aktaran, Tutkun, 2010, s.362).

Bireyler 21. yüzyıl becerilerini eğitim yoluyla çok daha disipline edilmiş şekilde kazanabilirler. 21.yüzyılın gerektirdiği becerilerin derslerle entegrasyonunun en önemli aracı ise öğretim programlarıdır. Ülkemizde de öğretim programlarında öğrencilere kazandırılması gereken beceriler konusu son y1llarda yapılan program güncelleme çalışmalarında daha fazla vurgulanmaktadır. Diğer taraftan öğretim programları ile kazandırılması hedeflenen becerilerin 21. yüzyıl becerileri ile ne kadar örtüşüyor olduğu cevaplanması gereken sorulardan biridir. Çünkü bu beceriler, öğrencilerin şimdi ve gelecekteki sosyal ve çalışma yaşamlarında başarılı olabilmeleri için gereklilik teşkil etmektedirler.

Ülkemizde de 2017 yılı başında öğretim programlarında güncelleme çalışmaları yapılmış ve taslak programlar, www.mufredat.meb.gov.tr adresi üzerinden kamuoyunun görüşüne sunulmuştur. Ayrıca 13.01.2017 tarihinde Talim ve Terbiye Kurulu Başkanlığının resmi internet sitesinde yayımlanan yazılı basın açıklaması metninde ilköğretim ve ortaöğretim kurumlarında okutulan derslere yönelik taslak programların hazırlandığı belirtilmiş ve bunun gerekçesi aşağıdaki şekilde açıklanmıştır (TTKB; 2017): 
Küreselleşen dünyada ve ülkemizde siyasi, sosyal, ekonomik, bilimsel ve teknolojik alanlarda yaşanan hızlı değişim ve gelişmeler, toplumun yeni yüzyılın mezunlarından beklentilerini farklılaştırmıştır. Temel bilgi ve becerilerin yanı sıra öğrencilerin bilgi çağı olarak adlandırılan günümüzde sahip olunması beklenen bilgi, beceri, tutumlara ilişkin farkındalık geliştirmeleri, bunları edinmeleri ve yaşamın farklı alanlarında uygulayabilecek donanıma ve alt yapıya sahip olmaları kaçınılmaz olmuştur. Bu nedenle aşağıdaki gerekçelerle güncelleme çalışmaları yapılmıştır.

1. Bireyin ve toplumun değişen ihtiyaçları,

2. Eğitimde niteliğin arttırılması ihtiyacı,

3. Bilim, teknoloji, öğrenme öğretme yaklaşım, kuram ve stratejilerinde son yıllarda yapılan araştırma ve çalışmalarla gerçekleşen değişiklikler ve gelişmeler,

4. Ulusal ve uluslararası değerlendirmelerde kullanılan ölçütler ve ülkemize ait bu değerlendirmelerin sonuçları,

5. Kalkınma Planları, 64. Hükümet Programı Eylem Planı (130 ve 132 numaralı Eylemler), 65. Hükümet Programı (2017 yılı Orta Vadeli Program), 2014-2019 MEB Stratejik Planı, OECD Eğitim Raporları,

6. Mevcut öğretim programlarının akademik bilgi bakımından yoğun olmasından dolayı "eğitim ve öğretimin" sadece öğretim boyutuna ağırlık verilmesi, eğitim boyutu için yeterli sürenin kalmaması gibi hususlar göz önünde bulundurularak çağın ve toplumun taleplerine cevap verebilecek donanıma ve üst düzey bilişsel becerilere sahip, bu becerileri yaşamının farklı alanlarında kullanabilen, millî, manevi ve evrensel değerleri benimseyerek bu değerleri tutum ve davranışa dönüştüren bireylerin yetiştirilmesine katkı sağlamak amacıyla öğretim programları revize çalışmaları yapılmıştır.

Yapılan açıklamada yeni yüzyılın bireylerden beklentilerine ve "bilgi çağı" olarak adlandırılan günümüzde sahip olunması beklenen bilgi, beceri, tutum ve değerleri edinmenin gereğine vurgu yapılmıştır. Bu bakış açısıyla öğretim programında revizyona gidilmiş olan derslerden biri de Sosyal Bilgiler dersidir.

Öğretim programlarının hazırlanma sürecinde, kazandırılması hedeflenen beceri ve değerlerin belirlenmesi önemli bir aşamadır. 2017 Sosyal Bilgiler Dersi Öğretim Programı (SBDÖP)'nda temel becerilerin önemi “okullarda gerçekleştirilen eğitim ve öğretim faaliyetlerinin ana çerçevesi olarak nitelendirilebilecek programlarda temel beceriler konusuna gereken yeri ve önemi vermek gerekmektedir" (MEB, 2017, s.6) ifadesi ile vurgulanmıştır.

TYÇ; Avrupa Yeterlilikler Çerçevesi (AYÇ) ile uyumlu olacak şekilde tasarlanan; ilk, orta ve yükseköğretim dâhil, meslekî, genel ve akademik eğitim ve öğretim programları ve diğer öğrenme yollarıyla kazanılan tüm yeterlilik esaslarını gösteren ulusal yeterlilikler çerçevesini ifade etmektedir(MEB, 2017, s.6, MYK, 2015, s.5).

02/01/2016 tarih ve 29581 sayılı Resmî Gazete'de yayımlanarak yürürlüğe giren TYÇ, Meslekî Yeterlilik Kurumunun koordinasyonunda Millî Eğitim Bakanlığı, Yükseköğretim Kurulu ve Meslekî Yeterlilik Kurumu temsilcilerinden oluşan Ulusal Yeterlilik Çerçevesi Hazırlama Komisyonu ve sosyal tarafların da dâhil olduğu teknik çalışma grupları tarafından hazırlanmış ve ilgili tüm kurum ve kuruluşların, yerli ve uluslararası konu uzmanlarının görüş ve önerileri alınarak nihai şeklini almıştır (MYK, 2015,s.i).

TYÇ’de hayat boyu öğrenme kapsamında her bireyin kazanması beklenen, tanımlanmış 8 anahtar yetkinlik bulunmaktadır. Çerçevede "anahtar yetkinlikler" 
kavramı "Bilgi toplumunun gerektirdiği, tüm bireylerin sahip olması gereken, kişilerin hayat boyu öğrenme çerçevesinde bireysel gelişimini, topluma etkin ve sorumlu bireyler olarak sosyal katılımlarını, istihdam edilebilmelerini destekleyen temel yetkinlikler" (MYK, 2015, s.41) şeklinde tanımlanmıştır. Ayrıca anahtar yetkinliklerin belirlenmesinin ilgili sorumlu kurumların (MEB, YÖK vb.), kazandırılmasının eğitim kuruluşlarının, ölçme, değerlendirme ve belgelendirmesi ise eğitim ve belgelendirme kuruluşlarının sorumluluğunda olduğu da belirtilmiştir (MYK, 2015, s.25). Bu açıklamalar ile MEB'in anahtar yetkinliklerin kazandırılmasında en önemli kurum olduğuna işaret edilmiştir.

Avrupa Parlamentosu ve Avrupa Konseyinin 18/12/2006 tarihli ve 2006/962/EC sayılı "Hayat Boyu Öğrenme İçin Anahtar Yetkinlikler" Hakkındaki Tavsiye Kararının ekinde "Hayat Boyu Öğrenme İçin Anahtar Yetkinlikler-Avrupa Referans Çerçevesi" ne yer verilmiştir. Avrupa Yeterlilikler Çerçevesi ve ona uyumlu olarak hazırlanmış olduğu belirtilen (MYK, 2015, s.5) TYÇ' de, her bir anahtar yetkinlik alanının içerdiği beceri ve değerler aşağıdaki şekilde tanımlanmaktadır (MYK, 2015, s.27):

1. Anadilde iletişim: Kavram, düşünce, fikir, duygu ve olguları hem sözlü hem de yazılı olarak ifade etme ve yorumlama (dinleme, konuşma, okuma ve yazma) ve eğitim ve öğretim, iş yeri, ev ve eğlence gibi her türlü sosyal ve kültürel bağlamda uygun ve yaratıcı bir şekilde dilsel etkileşimde bulunmaktadır.

2. Yabancı dillerde iletişim: Çoğunlukla ana dilde iletişimin temel beceri boyutlarını paylaşmakta olup duygu, düşünce, gerçek ve fikirleri hem sözlü hem de yazılı olarak kişinin istek ve ihtiyaçlarına göre eğitim, öğretim, iş yeri, ev ve eğlence gibi uygun bir dizi sosyal ve kültürel bağlamda anlama, ifade etme ve yorumlama becerisine dayalıdır. Yabancı dillerde iletişim, aracılık etme ve kültürlerarası anlayış becerilerini de gerektirmektedir. Bireyin yeterlilik seviyesi, bireyin sosyal ve kültürel geçmişi, çevresi, ihtiyaçları ve ilgilerine bağlı olarak dinleme, konuşma, okuma ve yazma boyutları ile farklı diller arasında değişkenlik gösterecektir.

3. Matematiksel yetkinlik ve bilim/teknolojide temel yetkinlikler: Matematiksel yetkinlik, günlük hayatta karşılaşılan bir dizi problemi çözmek için matematiksel düşünme tarzını geliştirme ve uygulamadır. Sağlam bir aritmetik becerisinin üzerine inşa edilen süreç, faaliyet ve bilgiye vurgu yapılmaktadır. Matematiksel yetkinlik, düşünme (mantıksal ve uzamsal düşünme) ve sunmanın (formüller, modeller, kurgular, grafikler ve tablolar) matematiksel modlarını farklı derecelerde kullanma beceri ve isteğini içermektedir.

Bilimde yetkinlik, soruları tanımlamak ve kanıta dayalı sonuçlar üretmek amacıyla doğal dünyanın açıklanmasına yönelik bilgi varlığı ve metodolojiden yararlanma beceri ve arzusuna atıfta bulunmaktadır. Teknolojide yetkinlik, algılanan insan istek ve gereksinimlerine karşıllk olarak bilgi ve metodolojinin uygulanması olarak görülmektedir. Bilim ve teknolojide yetkinlik, insan etkinliklerinden kaynaklanan değişimleri ve her bireyin vatandaş olarak sorumluluklarını kavrama gücünü kapsamaktadır.

4. Dijital yetkinlik: İş, günlük yaşam ve iletişim için bilgi toplumu teknolojilerinin güvenli ve eleştirel şekilde kullanılmasını kapsamaktadır. Söz konusu yetkinlik, bilgi iletişim teknolojisi içinde bilgiye erişim ve bilginin değerlendirilmesi, saklanması, üretimi, sunulması ve alışverişi için bilgisayarların kullanılması ayrıca internet aracıllğıyla ortak ağlara katılım sağlanması ve iletişim kurulması gibi temel beceriler yoluyla desteklenmektedir.

5. Öğrenmeyi öğrenme: Bireyin kendi öğrenme eylemini etkili zaman ve bilgi yönetimini de kapsayacak şekilde bireysel olarak veya grup halinde düzenleyebilmesi için öğrenmenin peşine düşme ve bu konuda 1srarc1 olma yeteneğidir. Bu yetkinlik, bireyin var olan olanakları tanıyarak öğrenme gereksinim ve süreçlerinin farkında olmasını ve başarılı bir öğrenme eylemi için zorluklarla başa çıkma yeteneğini kapsamaktadır. Bu yetkinlik, yeni bilgi ve beceriler kazanmak, işlemek ve kendine uyarlamak kadar rehberlik desteği aramak 
ve bundan yararlanmak anlamına da gelmektedir. Öğrenmeyi öğrenme, öğrenenleri bilgi ve becerilerin ev, iş yeri, eğitim ve öğretim ortamı gibi çeşitli bağlamlarda kullanılması ve uygulanması için önceki öğrenme ve yaşam deneyimlerine dayanılması yönünde harekete geçirmektedir. Motivasyon ve güven bireyin yetkinliği için çok önemlidir.

6. Sosyal ve vatandaşlıkla ilgili yetkinlikler: $\mathrm{Bu}$ yetkinlikler, kişisel, kişilerarası ve kültürlerarası yetkinlikleri içermekte; bireylerin, özellikle giderek farklılaşan toplumlarda sosyal ve çalışma yaşamına etkili ve yapıcı biçimde katılmalarına imkân tanıyacak; gerektiğinde çatışmaları çözecek özelliklerle donatılmasını sağlayan tüm davranış biçimlerini kapsamaktadır. Vatandaşlıkla ilgili yetkinlik ise, bireyleri, toplumsal ve siyasal kavram ve yapılara ilişkin bilgiye ve demokratik ve aktif katılım kararlılığına dayalı olarak medeni yaşama tam olarak katılmaları için donatmaktadır.

7. İnisiyatif alma ve girişimcilik: Bireyin düşüncelerini eyleme dönüştürme becerisini ifade etmektedir. Yaratıcılık, yenilik ve risk almanın yanında hedeflere ulaşmak için planlama yapma ve proje yönetme yeteneğini de içermektedir. Bu yetkinlik, herkesi sadece evde ve toplumda değil işlerine ait bağlam ve şartların farkında olabilmeleri ve iş firsatlarını yakalayabilmeleri için aynı zamanda iş yerinde desteklemekte; toplumsal ya da ticari etkinliklere girişen veya katkıda bulunan kişilerin ihtiyaç duydukları daha özgün bilgi ve beceri için de bir temel teşkil etmektedir. Etik değerlerin farkında olma ve iyi yönetişimi desteklemeyi kapsamaktadır.

8. Kültürel farkındalık ve ifade: Müzik, sahne sanatları, edebiyat ve görsel sanatlar da dâhil olmak üzere çeşitli kitle iletişim araçları kullanılarak görüş, deneyim ve duyguların yaratıcı bir şekilde ifade edilmesinin öneminin takdir edilmesidir.

TYÇ'de; ülkemiz eğitim politikalarında anahtar yetkinliklerin geniş ölçekte kazanılmasına öncelik verilmekte olduğu belirtilmiş ve "Anahtar yetkinliklerin eğitim ve öğretim programlarına ait öğrenme kazanımları içerisinde yer alması esastır" (MYK, 2015, s.28) ifadesine yer verilmiştir.

TYÇ'de yer alan anahtar yetkinlikler, hayat boyu öğrenme kapsamında her bireyin kazanması beklenen yetkinlikler (MYK, 2015,s. 26) olarak ifade edilmiş olsa da yenilenen diğer öğretim programlarında da (örneğin, Hayat Bilgisi, Fen Bilimleri, Matematik) dikkate alınmış olan bu yetkinliklerin farklı öğrenim düzeylerinde, farklı öğretim programları aracılığıyla da geliştirilmesinin beklendiği anlaşılmaktadır. 2017 yılında güncellenmiş olan SBDÖP ile de bu dersin TYÇ' de tanımlanan anahtar yetkinliklerin geliştirilmesini amaçlayan derslerden biri olduğu anlaşılmaktadır.

2017 SBDÖP'nda ise bu anahtar yetkinliklerin pek çoğunun birbiriyle uyumlu, birbirini kapsamakta ve birbirini desteklemekte olduğu, yetkinliklerin birbiri ile olan çok yönlü ilişkilerinin yanında bazı derslerin öğretim programlarındaki kazanımların sekiz yetkinlik alanından biri veya birkaçıyla daha yoğun bağlantılarının olduğu belirtilmiş ve şu ifadeye yer verilmiştir: "Sosyal Bilgiler Dersi Öğretim Programı başta sosyal ve vatandaşlıkla ilgili yetkinlikler alanı olmak üzere diğer yetkinlik alanlarının becerileriyle de güçlü ilişkiler içindedir" (MEB, 2017, ss.7-8). Bu doğrultuda "Sosyal ve Vatandaşlıkla İlgili Yetkinlikler", "İnisiyatif Alma ve Girişimcilik”, "Kültürel Farkındalık ve İfade" ve "Dijital Yetkinlik" alanlarıyla ilgili esas alınan becerilere yönelik ek bir açıklama yapılmıştır.

"Anahtar yetkinlik" kavramı; konuya ilişkin temel kaynaklardan olan Avrupa Komisyonunun "Key Competences For Lifelong Learning, European Reference Framework" başlıklı dokümanında, bilgi, beceri ve tutumların bir bileşimi olarak tanımlanmış ve bu yetkinliklerin tüm bireylerin kişisel gelişim, etkin vatandaşlık, sosyal katılım ve çalışma hayatı için gerekli olduğu belirtilmiştir (EC, 2007,s.3). Bu tanımlama 
ile anahtar yetkinlik alanlarının, beceriler ile birlikte değerleri de içerdiği anlaşılmaktadır.

2017 SBDÖP'nda, anahtar yetkinlik alanları ile birlikte kazandırılması hedeflenen beceri ve değerler ayrıca sıralanmıştır. Programda yer verilen beceri ve değerler Tablo 1'de gösterilmiştir(MEB, 2017, ss.9-10):

Tablo 1

2017 SBDÖP’nın “Ögrretim Programında Temel Beceriler” ve "Öğretim Programında Değerler Ĕ̈itimi” Başlıkları Altında Yer Verilen Beceri ve Değerler

Araştırma, Çevre okuryazarlığı, Değişim ve sürekliliği algılama, Dijital okuryazarlık, Eleştirel düşünme, Empati, Finansal okuryazarlık, Girişimcilik, Gözlem, Harita okuryazarlı̆̆ı, İletişim, İş birliği, Kalıp yargı ve önyargıyı fark etme, Kanıt kullanma, Karar verme, Konum analizi,

Beceriler Medya okuryazarlığı, Mekânı algılama, Öz denetim, Politik okuryazarlık, Problem çözme, Sosyal katılım, Tablo, grafik ve diyagram çizme ve yorumlama, Türkçeyi doğru, güzel ve etkili kullanma, Yenilikçi düşünme, Zaman ve kronolojiyi algilama

Değerler

Adalet, Aile birliğine önem verme, Bağımsızlık, Barış, Bilimsellik, Çalışkanlık, Dayanışma, Duyarlılık, Dürüstlük, Estetik, Eşitlik, Özgürlük, Saygı, Sevgi, Sorumluluk, Tasarruf, Vatanseverlik, Yardımseverlik

Tablo 1'de görüldüğü gibi 2017 SBDÖP’nın “Öğretim Programında Temel Beceriler" ve "Öğretim Programında Değerler Eğitimi” başlıkları altında 26 beceri ve 18 değer yer almaktadır.

MEB tarafından taslak öğretim programları görüş alınmak üzere askıya çıkarılmasından bu yana 2017 SBDÖP'nın gerek taslağı gerek son hali üzerinde bazı kurumlar tarafından inceleme ve araştırmalar yapılmıştır. Örneğin, Boğaziçi Üniversitesi, Eğitim Fakültesi (2017); Orta Doğu Teknik Üniversitesi, Eğitim Bilimleri Bölümü (2017); Eğitim-İş (2017); Eğitim-Sen (2017), hazırladıkları raporlar aracılığıyla 2017 SBDÖP hakkında görüş ve önerilerde bulunmuş; TEDMEM. (2017), öğretim programı taslaklarında değerler eğitimi hakkında görüş bildirirken, Eğitim Reformu Girişimi (2017) ise taslak sonrası uygulamaya konulan öğretim programları hakkında bir değerlendirme raporu hazırlamıştır. Ayrıca Gürel (2017) tarafından 2017 Sosyal Bilgiler Dersi Taslak Öğretim Programının yapısal bir değerlendirmesi yapılmış, Çakmak, Kaçar ve Arıkan (2017) ise aynı program hakkında öğretmen görüşlerine dayalı bir araştırma yürütmüşlerdir. Tay (2017), 2017 Sosyal Bilgiler Dersi Taslak Öğretim Programını 2005 SBDÖP ile karşılaştırmış, Koçoğlu ve Aydın (2017) ise taslak program sonrası uygulamaya konulan 2017 SBDÖP'nı 2005 SBDÖP çerçevesinde incelemiştir.

Alanyazın incelendiğinde, 2017 SBDÖP hakkında yürütülen çalışmaların oldukça sınırlı olduğu görünmektedir. 2017 SBDÖP'nın temel beceri ve değerlerinin TYÇ' de yer alan anahtar yetkinliklerle ilişkisini konu alan bir çalışmaya ise rastlanmamıştır. Ulusal yeterlilik çerçevesi olması açısından TYÇ ile tanımlanan anahtar yetkinliklerin, SBDÖP'nın yanı sıra tüm öğretim programları ile uyumu açısından incelenmesinin alanyazına katkı sağlayacağı düşünülmektedir. 
$\mathrm{Bu}$ çalışma ile 2017 SBDÖP'nın TYÇ'de yer alan anahtar yetkinliklerle ilişkisini ortaya koymak amaçlanmaktadır. Bu doğrultuda; 1. TYÇ’deki anahtar yetkinlik alanlarının; içerdiği beceri ve değerler açısından analiz edilmesi 2. SBDÖP'nın “Öğretim Programında Temel Beceriler” ve "Öğretim Programında Değerler Eğitimi” boyutlarının içeriği ile TYÇ’de yer alan anahtar yetkinlik alanlarının içeriğinin karşılaştırılması olmak üzere iki alt amaç belirlenmiştir.

\section{Yöntem}

\section{Araştırmanın Modeli ve Deseni}

Araştırma nitel araştırma modelinden yararlanılarak hazırlanmıştır. Creswell (1998) nitel araştırmayı, sosyal yaşamı ve insanla ilgili problemleri kendine özgü metotlarla sorgulayarak, anlamlandırma süreci olarak ifade etmektedir. Nitel çalışmalarda araştırmacı gözlem, görüşme ve doküman incelemesinden yararlanarak, kavramları, olguları, ilişkileri açıklamaya ve anlamaya çalışmaktadır. Verileri teker teker okuyarak, kodlar ve kategorize eder. Bu elde ettiği kodlara ve kategorilere dayalı olarak araştırma sonuçlarını ortaya koyar (Merriam, 1998,s.58)

Nitel araştırma modelinde pek çok araştırma deseni kullanılmaktadır. $\mathrm{Bu}$ araştırmada da nitel araştırma modeli kapsamında durum çalışması deseni kullanılmıştır. Durum çalışması, bir olguyu kendi gerçek yaşam çerçevesi içinde çalışan ve durumları çok yönlü, sistemli ve derinlemesine inceleyen görgül bir araştırma desenidir (Cohen\&Manion, 1997; McMillan, 2000; Patton, 1990; Yıldırım\& Şimşek, 2006). Durum çalışmaları sınıflamaları açısından bu çalışma genel amaçlı durum çalışmalarından, değerlendirmeye yönelik durum çalışmaları kapsamında yer almaktadır. Merriam (1998), değerlendirmeye yönelik durum çalışmalarını; tanımlama, açıklama ve muhakeme yapmayı gerektiren çalışmalar olarak tanımlamıştır. Bu çalışmada da TYÇ’nde yer alan anahtar yetkinliklerin, içerdiği beceri ve değerler açısından analiz edilmesi ve 2017 SBDÖP'nın “Temel Beceriler” ve "Değerler Eğitimi” boyutlarının, TYÇ’de yer alan anahtar yetkinliklerin içeriği ile karşılaştırılması amaçlanmıştır.

\section{Verilerin Toplanması}

Araştırmanın verileri araştırmanın amacına uygun olarak dokümandan elde edilmiştir. Doküman incelemesi araştırılması hedeflenen olgu ve olaylar hakkında bilgi içeren yazılı materyallerin analizini kapsar. Hangi dokümanların veri kaynağı olarak kullanılabileceği ise araştırma problemi ile yakından ilgilidir (Yıldırım \& Şimşek, 2006,ss. 140-141) Çalışmada öncelikle TYÇ'de yer alan anahtar yetkinliklere ilişkin açıklamalar analiz edilerek, içerdiği beceri ve değerler belirlenmiş̧tir. Bu amaçla kullanılan dokümanlardan biri 02/01/2016 tarih ve 29581 sayılı Resmî Gazete'de yayımlanan “Türkiye Yeterlilikler Çerçevesine Dair Tebliğ ve Eki” dir. Ayrıca TYÇ'de; sekiz anahtar yetkinliği belirleyen ve her bir yetkinliğe ilişkin temel bilgi, beceri, tutum ve davranışları tanımlayan "Hayat Boyu Öğrenme için Anahtar Yetkinlikler Hakkındaki Avrupa Parlamentosu ve Konseyinin Tavsiyesi” referans verilmiştir. Referans verilen çerçeve EC, 2006, Key Competences for Lifelong Learning-A European Reference Framework ise anahtar yetkinliklerin analiz edilmesinde kullanılan ikinci dokümandır. 
Kaynağa http://eur-lex.europa.eu/legal-content/EN/TXT/?uri=celex\% 3A32006H0962 adresinden ulaşılmıştır.

Her iki dokümanın analizi sonucunda elde edilen veriler ile 2017 SBDÖP'nın "Öğretim Programında Temel Beceriler" ve "Öğretim Programında Değerler Eğitimi" boyutlarının incelenmesinde kriter tablosu olarak kullanılacak olan Tablo 2 oluşturulmuştur. Daha sonra anahtar yetkinlik alanlarının içerdiği beceri ve değerler ile 2017 SBDÖP’nın, “Öğretim Programında Temel Beceriler” ve “Öğretim Programında Değerler Eğitimi” başlıkları altında sıralanmış olan 26 beceri ve 18 değer karşılaştırılmıştır.

MEB tarafından 18.07.2017 tarihinde yayımlanan ve araştırmada veri toplama araçları olarak kullanılan dokümanlardan olan 2017 SBDÖP'na http://mufredat.meb.gov.tr/ProgramDetay adresinden ulaşılmıştır.

Araştırma sürecinde SBDÖP da dâhil olmak üzere öğretim programlarında redaksiyon ve tashih düzeyinde olduğu belirtilen bazı düzeltme ve düzenlemeler yapılmış güncellenen öğretim programları 20 Ocak 2018 tarihinden itibaren http://mufredat.meb.gov.tr İnternet sitesi üzerinden kamuoyu ile paylaş1lmaya başlanmıştır. Bu araştırma 2017 SBDÖP ile sınırlandırılmıştır.

\section{Verilerin Analizi}

Araştırmada anahtar yetkinlik alanlarının içerdiği beceri ve değerleri gösteren Tablo-1'in oluşturulmasında kullanılan kaynaklar ve 2017 SBDÖP'nın “Öğretim Programında Temel Beceriler" ve "Öğretim Programında Değerler Eğitimi” boyutları nitel araştırma modelinde kullanılan veri analizi tekniklerden biri olan içerik analizi yoluyla incelenmiştir.

İçerik analizi çoğunlukla yazılı ve görsel verilerin analiz edilmesinde kullanılan bir yöntemdir. Bu yöntemde tümdengelimci bir yol takip edilmektedir. İçerik analizinde araştırmacı öncelikli olarak araştırma konusu ile ilgili kategoriler geliştirmektedir. Araştırmacı daha sonra, incelemiş olduğu veri setinde, bu kategoriler içerisine giren kelime, cümle ya da resimleri saymaktadır. Kategori geliştirme aşamasında araştırmacı dikkatli olmalı ve aynı metin üzerinde benzer bir araştırma yürütmeyi planlayan başka araştırmacıların da aynı sonuçlara ulaşabilecekleri türden uygun kategoriler geliştirmelidir (Silverman, 2001).

Araştırmada TYÇ'de yer alan anahtar yetkinlik alanları ile 2017 SBDÖP'nın “Öğretim Programında Temel Beceriler" ve "Öğretim Programında Değerler Eğitimi” boyutları içerdikleri beceri ve değerler açısından karşıllaştırılmıştır.

Miles ve Huberman (1994) nitel veri analizi sürecini, birbirini takip eden üç aşamalı bir sınıflandırma içerisinde incelemektedir. Bu aşamalardan ilkini gözlem, görüşme ve doküman incelemesi gibi çeşitli tekniklerle toplanan "verilerin azaltılması" (data reduction) aşaması oluşturmaktadır. Bu aşamada, alandan toplanmış ve henüz işlenmemiş durumda bekleyen veri seti, ayıklama, özetleme ve dönüştürme işlemlerinden geçirilmektedir. Veri azaltma aşaması, araştırma raporunun tamamlanmasına kadar süren uzun bir süreci kapsamaktadır. Veri azaltma sürecinde araştırmacı, araştırmanın amacına göre hangi verileri araştırmanın dışında bırakacağına, hangi verileri kullanacağına ve veri setini nasıl sınıflandıracağına karar vermektedir. 
Veri analizinin ikinci basamağını ise "verilerin görsel hale getirilmesi" süreci oluşturmaktadır. $\mathrm{Bu}$ aşamada, veri azaltılması sürecinde ayıklanan, özetlenen ve dönüştürülen verilerin belirli sonuçlar çıkartmaya dönük bir biçimde örülmesi amaçlanmaktadır.

Miles ve Huberman'ın (1994) önermiş olduğu veri analiz sürecinin son basamağını ise "sonuca ulaşma ve teyit etme" oluşturmaktadır. Bir bakıma nitel araştırmacı araştırma sürecinin başından itibaren sürecin her aşamasında toplamış olduğu verilerin ne anlama geldiğini anlamaya çalışmaktadır.

Araştırmanın güvenirliğini sağlamak amacıyla, öncelikle araştırmada kriter tablosu olarak kullanılan Tablo 2'nin hazırlanması için çalışılmıştır. Tablo 2'de, kaynaklara göre her bir yetkinlik alanı başlığı altında yer verilen beceri ve değerlere ait ifadelerin ilgili yetkinlik alanını temsil edip etmediği ve kaynaklarda yer alan ilgili ifadelere tabloda yer verilip verilmediği konusunda iki araştırmacının analiz sonuçları karşılaştırılmıştır. Ayrıca SBDÖP'nda analiz edilen “Öğretim Programında Temel Beceriler" ve "Öğretim Programında Değerler Eğitimi” boyutlarının analiz sonuçlarını gösteren Tablo 3 ile Tablo 4 iki araştırmacı tarafından ayrı ayrı oluşturulmuş ve sonuçları karşılaştırılmıştır. Araştırma verileri iki araştırmacı tarafından ayrı ayrı kodlandıktan sonra ortaya çıkan tablolara son şekli verilmiştir. Araştırmacıların birbirinden bağımsız olarak kullandıkları ifadelerin tutarlılığg "Görüş birliği” ya da "Görüş ayrılığı" şeklinde işaretlemeler yapılarak belirlenmiştir. Araştırmacılar tarafından dokümanlarda geçen aynı ifadeler için aynı yetkinlik alanının uygun bulunduğu durumlar; görüş birliği, farklı yetkinlik alanının uygun bulunduğu durumlar ise görüş ayrılığı olarak kabul edilmiştir. Her iki araştırmacı tarafından çelişkiye düşülen ifadelerde diğer araştırmacının görüşüne başvurulmuştur (Miles \&Huberman, 1994). Uzmanlar arasındaki ortalama uyum değeri Tablo 2 için, \%93; Tablo 3 için, \%92; Tablo 4 için, \%85 olarak bulunmuştur.

\section{Bulgular}

Araştırmanın bulguları;

TYÇ’de Yer Alan Anahtar Yetkinlik Alanlarının Analizi

“Öğretim Programında Temel Beceriler” Başlı̆̆ı Altında Sıralanan Beceriler ile Anahtar Yetkinlik Alanlarının İçerdiği Becerilerin Karşılaştırılması

“Öğretim Programında Değerler Eğitimi” Başlığı Altında Sıralanan Değerler ile Anahtar Yetkinlik Alanlarının İçerdiği Değerlerin Karşılaştırılması

başlıkları altında düzenlenmiştir.

\section{TYÇ'de Yer Alan Anahtar Yetkinlik Alanlarının Analizi}

Tablo 2' de TYÇ'de yer alan anahtar yetkinlik alanlarının hangi beceri ve değerleri içerdiğinin ortaya konulması amacıyla anahtar yetkinlik alanlarının tanımlandığı kaynaklardan olan 02/01/2016 tarih ve 29581 sayılı Resmî Gazete'de yayımlanan "Türkiye Yeterlilikler Çerçevesine Dair Tebliğ ve Eki” ile TYÇ' de referans verilen "Hayat Boyu Öğrenme için Anahtar Yetkinlikler Hakkındaki Avrupa Parlamentosu ve Konseyinin Tavsiyesi” analiz edilmiştir. 
Tablo 2

\section{TYÇ'de Yer Alan Anahtar Yetkinlik Alanlarının Analizi}

\section{Anahtar Yetkinlik Alanları Yetkinlikler}

Anadilde İletişim

Yabanc1 Dillerde İletişim*

Matematiksel Yetkinlik ve Bilim Teknolojide Temel Yetkinlikler

Dijital Yetkinlik

Öğrenmeyi Öğrenme

Sosyal ve Vatandaşlıkla

İlgili Yetkinlikler

İnisiyatif Alma ve

Girişimcilik Yetkinliği

Kültürel Farkındalık ve İfade Yetkinliği
Sözlü ifade, Yazılı ifade, Okuma, Anlama, Yorumlama, Bağlama uygun ve yaratıcı dilsel etkileşim, Estetik

Sözlü ifade, Yazılı ifade, Okuma, Anlama, Yorumlama, Aracılık etme, Kültürler arası anlayış, Farklı dillere ve kültürlere merak ve ilgi

Matematiksel düşünme, Aritmetik, Mantıksal ve uzamsal düşünme, Formüle etme, Modelleme, Tablo, grafik okuma, Problem çözme, Kanıta dayalı sonuca varma, Bilimsel merak ve araştırma, Bilgi varlığından ve metodolojiden yararlanma, Bilim ve teknolojideki değişimi takip etme, Bilim ve teknolojideki gelişme konusunda sorumluluk alma, Bilim ve teknolojinin doğaya etkilerini fark etme, Bilimsel bakış açısı, Nedensonuç ilişkisi kurma, Eleştirel düşünme, Gözlem

Bilgi toplumu teknolojilerini güvenli kullanma, Bilgi toplumu teknolojilerini eleştirel kullanma, Bilgi toplumu teknolojilerini kullanarak bilgiye erişme, Bilgi toplumu teknolojileri aracılığıyla edindiği bilgiyi değerlendirme, Bilgiyi saklama, üretme ve bilgi alışverişi için bilgisayar kullanma, İnternet aracılığıyla ortak ağlara katılma ve iletişim kurma, Gerçeği ve sanalı ayırt etme, İnteraktif medyayı sorumlu bir şekilde kullanma

Kendi öğrenme sürecini yönetme, Etkili zaman ve bilgi yönetimi, Öğrenme konusunda istekli ve 1srarc1 olma, Öğrenme ihtiyacını fark etme, Öğrenme sürecindeki zorluklarla başa çıkma, Yeni bilgi ve beceriyi kendine uyarlama, Edindiği bilgi ve becerilerden yararlanma, Önceki öğrenme ve deneyimlerinden hareket etme, Araştırma, Hayat boyu öğrenmeye inanma, Motivasyon

Toplumsal yaşama etkin ve yapıcı katılım, Demokratik tutum, Çatışma ve sorun çözme, Toplumsal ve siyasal yapıyı kavrama, Toplumsal değişime uyum, İş yaşamına etkin katılım ve meslek seçimi, Hoşgörü-Tolerans gösterme, Empati, Farklı bakış açılarını anlama, Yapıcı iletişim, Arabuluculuk yapma, Çok kültürlü anlayış, Stres ve öfkeyle başa çıkma, Önyargı ve kalıp yargının üstesinden gelme, Kişisel ve profesyonel dünyayı ayırt etme, Dayanışma, Karar alma süreçlerine katılma, Oy kullanma, İnsan haklarına saygı, Eşitlik, Adalet, Farklılıklara saygı, Vatandaşlık, Dürüst ve güvenilir olma, Sorumluluk, Sağlıklı yaşam, Küresel farkındalık, Müzakere ve uzlaşma

Düşüncelerini eyleme dönüştürme, Yaratıcılık ve yenilik, Risk alma, Planlama, Proje yönetme, İçinde bulunduğu bağlam ve şartların farkında olma, Fırsatları değerlendirme, İletişim, Liderlik, Etkili sunum, İş birliği halinde çalışma, Raporlama ve sunma, Etik değerlerin farkında olma, İyi yönetişimi destekleme, Ekonomik farkındalık, Kararlılık

Görüş, deneyim ve duygularını, sanat ya da kitle iletişim araçları aracılığıyla ifade etme, Duygu, düşünce ve deneyimlerini sanat aracılığıyla ifade etmenin önemini takdir etme, Sanatla ilgili çalışmalardan zevk alma, Kültürel çeşitliliğe saygı, Kültürel aktivitelerle ilgili sosyal ve ekonomik firsatlardan yararlanma, Kültürel mirasa duyarlılık, Estetik, Yaratıcılık, Kültüre ve sanata saygı

\footnotetext{
* "Yabancı Dillerde İletişim” yetkinlik alanı, "TYÇ’de Yer Alan Anahtar Yetkinlik Alanlarının Analizi” olarak adlandırılmış Tablo 1 ' de analiz edilen yetkinlik alanlarından biri olarak yer almıştır. Ancak genel amaçlar da dikkate alındığında Sosyal Bilgiler Dersi kapsamında bu alana ilişkin yetkinliklerin yer alması beklenmemektedir (MEB, 2017,s.5). Bu nedenle "Yabancı Dillerde İletișim"
} 
yetkinlik alanının içerdiği beceri ve değerler araştırmanın ikinci amacı olan "2017 SBDÖP’nda yer alan "Temel Beceriler" ve "Değerler Eğitimi" boyutlarının içeriğinin TYÇ ile belirlenen anahtar yetkinlik alanlarının içeriği ile karşılaştırılması boyutunda Program'da aranmayacaktır. Bu gerekçe doğrultusunda "Yabancı Dillerde İletişim" yetkinlik alanına Tablo 2 ve Tablo 3" de yer verilmemişsir.

Tablo 2'de de görüldüğü gibi, TYÇ'de sekiz anahtar yetkinlik alanı yer almaktadır. Bunlar sırasıyla; anadilde iletişim, yabancı dillerde iletişim, matematiksel yetkinlik ve bilim teknolojide temel yetkinlikler, dijital yetkinlik, öğrenmeyi öğrenme, sosyal ve vatandaşlıkla ilgili yetkinlikler, inisiyatif alma ve girişimcilik yetkinliği, kültürel farkındalık ve ifade yetkinliğidir. Anahtar yetkinliklerin tanımlandığı kaynakların analizi sonucunda, her bir anahtar yetkinlik alanına uygun beceri ve değer ifadeleri Tablo 2'de gruplanmıştır. Buna göre, en fazla ifade $(\mathrm{f}=28)$, "Sosyal ve Vatandaşlıkla İlgili Yetkinlikler" altında yer almıştır. Bu nedenle anahtar yetkinlikler arasında en geniş kapsamlı yetkinlik alanının "Sosyal ve Vatandaşlıkla İlgili Yetkinlikler" olduğu söylenebilir. Bu yetkinlik alanını "Matematiksel Yetkinlik ve Bilim Teknolojide Temel Yetkinlikler" (f=17) ile "İnisiyatif Alma ve Girişimcilik Yetkinliği” (f=16) "takip etmektedir. Tabloda "Öğrenmeyi Öğrenme” yetkinlik alanı altında 11, "Kültürel Farkındalık ve İfade Yetkinliği" altında ise 9 ifade yer almıştır. Ayrıca tabloda "Yabancı Dillerde İletişim" ve "Dijital Yetkinlik" alanları 8'er ifade ile tanımlanırken, "Anadilde İletişim" yetkinlik alanına ait 7 ifadeye yer verilmiştir. Tabloda da görüldüğü gibi kaynaklarda en az ifade ile tanımlanan yetkinlik alanı "Anadilde İletişim” dir.

Anahtar yetkinlik alanlarının her birine ilişkin beceri ve değerleri gösteren ve araştırmada kriter olarak kullanılan Tablo 2' den yararlanılarak, 2017 SBDÖP'nda incelenen "Öğretim Programında Temel Beceriler" ve "Öğretim Programında Değerler Eğitimi” boyutlarının analizine ait bulgular aşağıda Tablo 3 ve Tablo 4 'te açıklanmıştır.

\section{“Öğretim Programında Temel Beceriler" Başlığı Altında Sıralanan Beceriler ile Anahtar Yetkinlik Alanlarının İçerdiği Becerilerin Karşılaştırılması}

Araştırmanın bu aşamasında 2017 SBDÖP'nda “Öğretim Programında Temel Beceriler" başlığı altında sıralanan beceriler ile TYÇ'nde tanımlanan anahtar yetkinlik alanlarının içerdiği beceriler karşılaştırılmıştır.

Tablo 3'te 2017 SBDÖP'nın temel becerilerinin anahtar yetkinlik alanlarına göre dağılımı ve frekansları gösterilmektedir. 


\section{Tablo 3}

\section{SBDÖP’nın Temel Becerilerinin Anahtar Yetkinlik Alanlarına Göre Dağılımı}

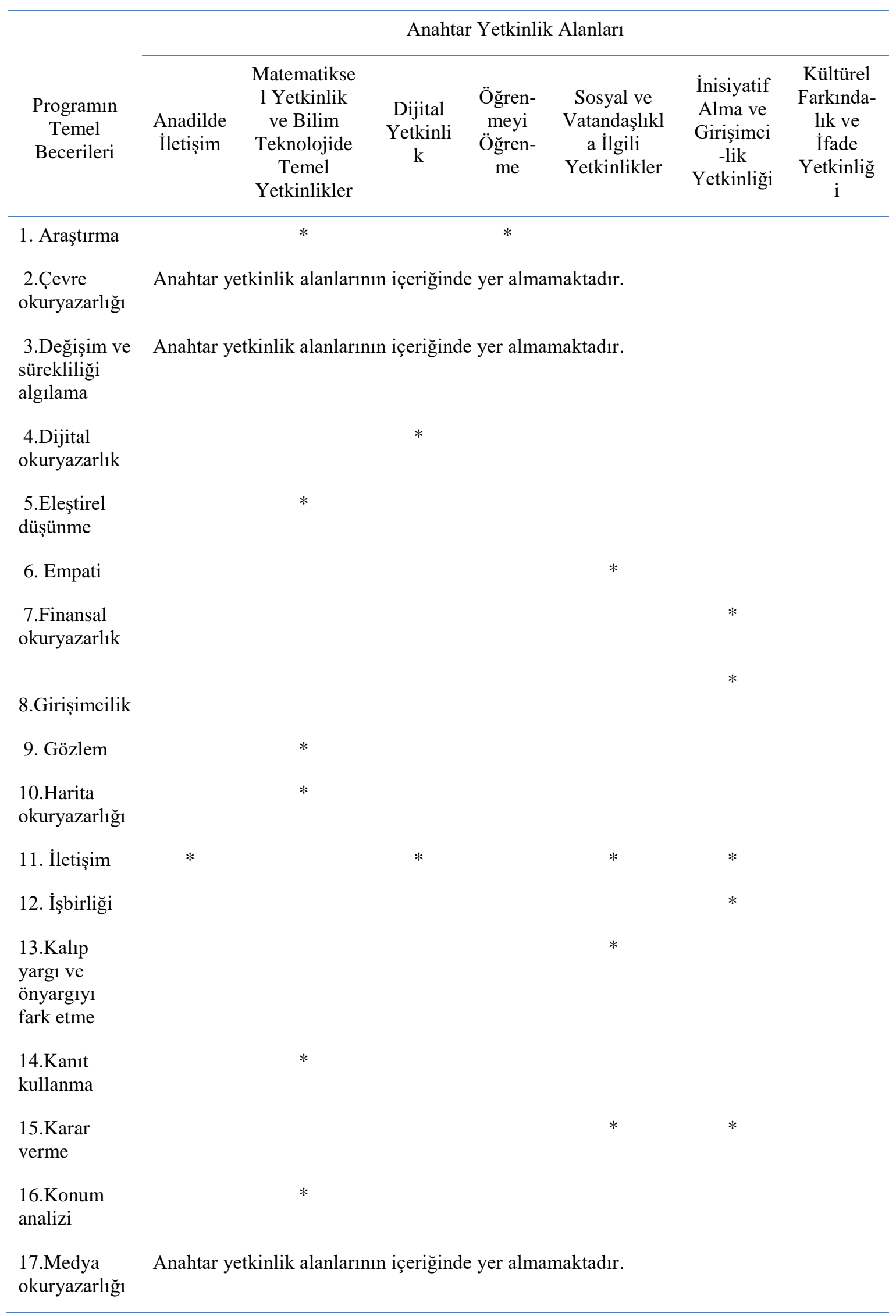


Tablo 3 (devamı)

2017 SBDÖP'nın Temel Becerilerinin Anahtar Yetkinlik Alanlarına Göre Dağılımı

\begin{tabular}{|c|c|c|c|c|c|c|c|}
\hline \multirow[b]{2}{*}{$\begin{array}{l}\text { Programın } \\
\text { Temel } \\
\text { Becerileri }\end{array}$} & \multicolumn{7}{|c|}{ Anahtar Yetkinlik Alanları } \\
\hline & $\begin{array}{l}\text { Anadild } \\
\text { e } \\
\text { İletişim }\end{array}$ & $\begin{array}{c}\text { Matematikse } \\
1 \text { Yetkinlik } \\
\text { ve Bilim } \\
\text { Teknolojide } \\
\text { Temel } \\
\text { Yetkinlikler }\end{array}$ & $\begin{array}{c}\text { Dijital } \\
\text { Yetkinli } \\
\text { k }\end{array}$ & $\begin{array}{l}\text { Öğren } \\
\text {-meyi } \\
\text { Öğren } \\
\text {-me }\end{array}$ & $\begin{array}{c}\text { Sosyal ve } \\
\text { Vatandaşlıkl } \\
\text { a İlgili } \\
\text { Yetkinlikler }\end{array}$ & $\begin{array}{l}\text { İnisiyatif } \\
\text { Alma ve } \\
\text { Girişimci } \\
\text {-lik } \\
\text { Yetkinliği }\end{array}$ & $\begin{array}{c}\text { Kültürel } \\
\text { Farkında- } \\
\text { lık ve } \\
\text { İfade } \\
\text { Yetkinliğ } \\
\text { i }\end{array}$ \\
\hline $\begin{array}{l}\text { 18.Mekânı } \\
\text { algılama }\end{array}$ & & * & & & & & \\
\hline $\begin{array}{l}\text { 19.Özdeneti } \\
\text { m }\end{array}$ & & & & & $*$ & & \\
\hline $\begin{array}{l}\text { 20.Politik } \\
\text { okuryazarlık }\end{array}$ & & & & & * & & \\
\hline $\begin{array}{l}\text { 21.Problem } \\
\text { çözme }\end{array}$ & & * & & & $*$ & & \\
\hline $\begin{array}{l}\text { 22.Sosyal } \\
\text { katılım }\end{array}$ & & & $*$ & & $*$ & & \\
\hline $\begin{array}{l}\text { 23.Tablo, } \\
\text { grafik ve } \\
\text { diyagram } \\
\text { çizme ve } \\
\text { yorumlama }\end{array}$ & & * & & & & & \\
\hline $\begin{array}{l}\text { 24.Türkçeyi } \\
\text { doğru, güzel } \\
\text { ve etkili } \\
\text { kullanma }\end{array}$ & $*$ & & & & & & \\
\hline $\begin{array}{l}\text { 25.Yenilikçi } \\
\text { düşünme }\end{array}$ & & & & & & * & \\
\hline $\begin{array}{l}\text { 26.Zaman ve } \\
\text { kronolojiyi } \\
\text { algilama }\end{array}$ & Anahtar s & tkinlik alanları & n içeriğind & yer alm & naktadir. & & \\
\hline Toplam $f$ & 2 & 9 & 3 & 1 & 8 & 6 & 0 \\
\hline
\end{tabular}

Tablo 3'te de görüldüğü gibi, 2017 SBDÖP'nda, anahtar yetkinlik alanları içinde en fazla $(f=9)$ "Matematiksel Yetkinlik ve Bilim Teknolojide Temel Yetkinlikler" e ait becerilere yer verilmiştir. Bu beceriler, araştırma, eleştirel düşünme, gözlem, harita okuryazarlığı, kanıt kullanma, konum analizi, mekânı algılama, problem çözme ile tablo, grafik ve diyagram çizme ve yorumlamadır. Beceriler, ilgili bulundukları anahtar yetkinlik alanları ile şu şekilde ilişkilendirilmişlerdir.

Araştırma becerisi; “Öğrenmeyi Öğrenme” yetkinlik alanı içerisinde aynı şekilde ifade edilmiş, "Matematiksel Yetkinlik ve Bilim Teknolojide Temel Yetkinlikler" alanında ise "bilimsel merak ve araştırma" ifadesi şeklinde yer almıştır.

Eleştirel düşünme becerisi ile gözlem becerisi, "Matematiksel Yetkinlik ve Bilim Teknolojide Temel Yetkinlikler” alanı altında aynı ifade ile yer almıştır. 
Harita okuryazarlığı, konum analizi ve mekânı algılama becerileri ise "Matematiksel Yetkinlik ve Bilim Teknolojide Temel Yetkinlikler" alanı altında "mantıksal ve uzamsal düşünme" yetkinliğine uygun bulunmuştur. Bu ilişkiye dayanak olarak ilgili literatürdeki görüşlerden yararlanılmıştır. Bu görüşlerden biri olan Bednarz (2001)'e göre, uzamsal ilişkiler, coğrafya eğitiminde en çok geliştirilen uzamsal düşünce aşamalarıdır. Bednarz, görsel- uzamsal düşünme becerileri arasında, mekânları birbiriyle ilişkilendirmek, belirlenmiş ölçütlere göre gerçek dünyada yön bulmak, harita taslağı yapmak, haritaları karşılaştırmak gibi becerilere yer vermiştir (Bednarz, 2001).

Kanit kullanma becerisi, "Matematiksel Yetkinlik ve Bilim Teknolojide Temel Yetkinlikler" içerisinde yer alan "kanıt kullanarak sonuca varma" yetkinlik ifadesini karş1lar kabul edilmiştir.

Problem çözme becerisi, "Matematiksel Yetkinlik ve Bilim Teknolojide Temel Yetkinlikler" içerisinde aynı ifade ile yer almaktadır.

Tablo, grafik ve diyagram çizme ve yorumlama becerisi, "Matematiksel Yetkinlik ve Bilim Teknolojide Temel Yetkinlikler" içerisinde, "tablo, grafik okuma" şeklinde ifade edilmiştir.

2017 SBDÖP'nın becerileri içerisinde en fazla $(f=8)$ yer alan ikinci anahtar yetkinlik alanı ise "Sosyal ve Vatandaşlıkla İlgili Yetkinlikler" dir. Programın becerileri arasında bu alana ait olan beceriler, empati, iletişim, kalıp yargı ve önyargıyı fark etme, karar verme, politik okuryazarlık, problem çözme ve sosyal katılım olarak belirlenmiştir. Bu beceriler, ilgili bulundukları anahtar yetkinlik alanları ile şu şekilde ilişkilendirilmişlerdir.

Empati becerisi, "Sosyal ve Vatandaşlıkla İlgili Yetkinlikler" içerisinde aynı ifade ile yer almıştır.

İletişim becerisi, "Sosyal ve Vatandaşlıkla İlgili Yetkinlikler” içerisinde "yapıcı iletişim" ifadesi ile yer almıştır.

Kalıp yargı ve önyargıyı fark etme becerisi, "Sosyal ve Vatandaşlıkla İlgili Yetkinlikler" arasında “ön yargı ve kalıp yargının üstesinden gelme” yetkinliği olarak ifade edilmiştir.

Karar verme becerisi ise, "Sosyal ve Vatandaşlıkla İlgili Yetkinlikler" den "karar alma süreçlerine katılma" ve "oy kullanma” ile "İnisiyatif Alma ve Girişimcilik" yetkinlik alanından "kararlılık" yetkinlikleri ile ilişkili bulunmuştur.

Öz denetim becerisi, "Sosyal ve Vatandaşlıkla İlgili Yetkinlikler" içerisinde "stres ve öfkeyle başa çıkma”, "önyargı ve kalıp yargının üstesinden gelme” ile "kişisel ve profesyonel dünyayı ayırt etme" ifadeleri ile yer almıştır.

Politik okuryazarlık becerisi, "Sosyal ve Vatandaşlıkla İlgili Yetkinlikler" den "karar alma süreçlerine katılma", "oy kullanma" ile "toplumsal ve siyasal yapıyı kavrama" ile ilişkili bulunmuştur. Bu ilişkiye dayanak olarak yararlanılan tanımlardan birini Doğanay, Çuhadar ve Sarı (2007) yapmıştır. Tanıma göre, politik okuryazarlık; en genel anlamıyla siyasal sistemler içerisinde vatandaşların yöneticiler ve alınan siyasi kararlar üzerinde söz sahibi olmasıdır.

Problem çözme becerisi, "Sosyal ve Vatandaşlıkla İlgili Yetkinlikler” altında "çatışma ve sorun çözme" ifadesi ile yer almaktadır. 
Sosyal katılım becerisi, "Sosyal ve Vatandaşlıkla İlgili Yetkinlikler" den, "toplumsal yaşama etkin ve yapıcı katılım" ile "iş yaşamına etkin katılım ve meslek seçimi"ne uygun bulunmuştur.

Programda "İnisiyatif Alma ve Girişimcilik" yetkinliğine ait 6 beceri yer almıştır. Bunlar; finansal okuryazarlık, girişimcilik, iletişim, iş birliği, karar verme ve yenilikçi düşünmedir.

Çalışmada bu beceriler, ilgili bulundukları anahtar yetkinlik alanları ile şu şekilde ilişkilendirilmişlerdir:

Finansal okuryazarlık becerisi, PISA 2012 raporunda aşağıdaki temel esaslar kriter alınarak ölçülmüştür (OECD, 2012):

1. Paranın farklı biçim ve amaçlarının farkında olma, günlük harcamalar, ödemeler, para değeri, banka hesapları, para birimlerine ilişkin parasal işlemleri yürütebilme yeterliği,

2. Geliri ve varlığı kısa ve uzun vadede planlama ve yönetme becerisi, gelir ve diğer kaynakları finansal iyi olma halini geliştirebilmek için kullanma yeterliği,

3. Finansal kayıp ve risklerin farkında olma, kredi kullanımı ve faiz oranlarını kavrayabilme yeterliği

4. Tüketici hakları ve sorumluluklarının farkında olma, ekonomik koşullardaki ve devlet politikalarındaki değişimin sonuçlarını kavrayabilme yeterliği.

$\mathrm{Bu}$ yeterlikler açısından "finansal okuryazarlık" becerisi anahtar yetkinlikler arasında aynı ifade ile yer almasa da içeriği bakımından "İnisiyatif Alma ve Girişimcilik" alanı içinde yer alan "risk alma, planlama, içinde bulunduğu bağlam ve şartların farkında olma, fırsatları değerlendirme ve ekonomik farkındalık" gibi yetkinlikler ile uyumlu bulunmuştur.

Girişimcilik becerisi, "İnisiyatif Alma ve Girişimcilik" yetkinliğinin geneli ile ilişskili bulunmuş, iletişim becerisi ise, anahtar yetkinliklerden "İnisiyatif Alma ve Girişimcilik" alanı altında aynı ifadeler ile yer almıştır.

İş birliği becerisi, "İnisiyatif alma ve girişimcilik" yetkinlik alanı altında yer alan “iş birliği halinde çalışma" yetkinliği şeklinde ifade edilmiştir.

Karar verme becerisi, "Sosyal ve Vatandaşlıkla İlgili Yetkinlikler" den "karar alma süreçlerine katılma", "oy kullanma" ile "inisiyatif alma ve girişimcilik" yetkinlik alanından ise "kararlılık" yetkinlikleri ile ilişkili bulunmuştur.

Yenilikçi düşünme becerisi ise "inisiyatif alma ve girişimcilik" alanı içerisinde "yaratıcılık ve yenilik" yetkinliğinin sadece yenilik boyutunu karşılamaktadır.

2017 BDÖP becerileri arasında "Dijital Yetkinlik" alanına uygun 3, "Anadilde İletişım" yetkinlik alanına uygun 2 beceri yer almıştır. $\mathrm{Bu}$ becerilerden "dijital okuryazarlık", "sosyal katılım" ve "iletişim" becerileri "Dijital Yetkinlik" alanına, "Türkçeyi doğru, güzel ve etkili kullanma" ve "iletişim" ise "Anadilde İletişim" yetkinlik alanına yönelik becerilerdir. "Öğrenmeyi Öğrenme" yetkinlik alanına Programda uygun bulunan tek beceri ise "araştırma"dır.

Çalışmada bu beceriler, ilgili bulundukları anahtar yetkinlik alanları ile şu şekilde ilişkilendirilmişlerdir. 
“Türkçeyi doğru, güzel ve etkili kullanma” ve "iletişim” becerileri TYÇ’deki anahtar yetkinlik alanlarından biri olan "Anadilde İletişim” yetkinliğinin bütünüyle ilişkilidir.

Dijital okuryazarlık becerisi; TYÇ'de "Dijital Yetkinlik" adı altında bir anahtar yetkinlik alanı olarak geçmektedir. "Okuryazarlık” kavramı doğrultusunda tanımlanmış olan içeriğiyle, "Dijital Yetkinlik" alanının içeriğini kapsamaktadır. Ayrıca Programda yer verilen "sosyal katılım" becerisi de bu yetkinlik alanı altında yer alan "internet aracılığıyla ortak ağlara katılma ve iletişim kurma" ifadesine uygun bulunmuştur.

Araştırma becerisi ise; “Öğrenmeyi Öğrenme” yetkinlik alanında aynı ifade ile yer almıştır.

Tablo 3' te de görüldüğü gibi, 2017 SBDÖP'nda “Kültürel Farkındalık ve İfade Yetkinliğgi" ne ait herhangi bir beceri yer almamıştır.

2017 SBDÖP'nda sıralanan 26 beceri arasında ayrıca “çevre okuryazarlığı, değişim ve sürekliliği algılama, medya okuryazarlığı ile zaman ve kronolojiyi algılama” becerilerine de yer verilmiştir. Bu beceriler TYÇ'nde tanımlanmış anahtar yetkiliklerin içeriği ile yakın ilişkili bulunmamıştır. Diğer bir deyişle programda "Öğretim Programında Temel Beceriler" başlığı altında sıralanan 26 beceriden, 22'sinin anahtar yetkinlik alanları ile yakından ilişkili olduğu, diğer 4 becerinin ise programın önemsediği ve anahtar yetkinliklere ek olarak yer verilen beceriler olduğu düşünülebilir.

\section{“Öğretim Programında Değerler Eğitimi” Başlığı Altında Sıralanan Değerler ile Anahtar Yetkinlik Alanlarının İçerdiği Değerlerin Karşılaştırılması}

Tablo 4' te 2017 SBDÖP'nda “Öğretim Programında Değerler Eğitimi” başlı̆̆1 altında sıralanan 18 değerin anahtar yetkinliklerle ilişkisine yönelik yapılan analiz sonucu yer almaktadır. 
Tablo 4

2017 SBDÖP'nda Yer Alan Değerlerin Anahtar Yetkinlik Alanlarına Göre Dağılımı

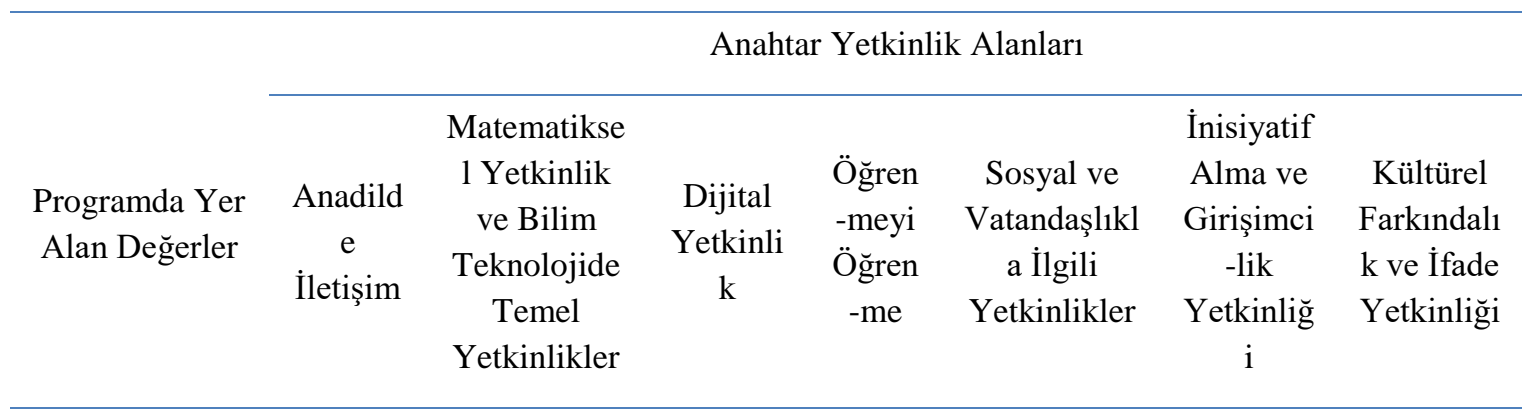

1.Adalet

2.Aile birliğine Anahtar yetkinlik alanlarının içeriğinde yer almamaktadır. önem verme

3.Bağımsızlık

4.Barıș

5.Bilimsellik

6.Çalışkanlık

7.Dayanışma

8.Duyarlilık

9.Dürüstlük

10.Estetik

11.Eşitlik

12.Özgürlük Anahtar yetkinlik alanlarının içeriğinde yer almamaktadır.

13.Sayg1

14.Sevgi Anahtar yetkinlik alanlarının içeriğinde yer almamaktadır.

15.Sorumluluk

16.Tasarruf Anahtar yetkinlik alanlarının içeriğinde yer almamaktadır.

17.Vatansever- Anahtar yetkinlik alanlarının içeriğinde yer almamaktadır. lik

18.Yardımseve Anahtar yetkinlik alanlarının içeriğinde yer almamaktadır. r-lik

$\begin{array}{llllllll}\text { Toplam } f & 1 & 2 & 0 & 1 & 7 & 0 & 3\end{array}$

Tablo 4' te görüldüğü gibi Programda en fazla $(f=7)$ "Sosyal ve Vatandaşlikla İlgili Yetkinlikler” alanıyla ilişkili değerlerin yer aldığı görülmektedir. Bu 7 değer; adalet, barış, dayanışma, dürüstlük, eşitlik, saygı ve sorumluluktur.

$\mathrm{Bu}$ değerler, TYÇ'de yer alan anahtar yetkinlik alanları ile şu şekilde ilişkilendirilmişlerdir: 
Adalet, dayanışma, eşitlik ve sorumluluk değerleri "Sosyal ve Vatandaşlıkla İlgili Yetkinlikler" altında da aynı ifadelerle yer almıştır.

Barış kavramının tanımına yönelik ilgili literatür incelendiğinde içerisinde pek çok değer barındırdığı görülmektedir. Örneğin Lyon'a göre barış; herkesin çatışma, ön yargı, düşmanlık ya da haksızlık gibi engeller olmadan yaşayabilmesi ve başarılı olabilmesidir. Barış; her bireyin diğer tüm bireylerin haklarını tam olarak kazanması için üzerine düşen tüm sorumluluğu yerine getirmesiyle sağlanan bir durumdur. Barış; çatışmaya ve farklılıklara hoşgörü ve esneklikle tepki verme sürecidir (Schrumpf, Crawford\&Bodine, 2007: 164; aktaran, Aktaş \& Safran, 2013, ss. 137). Bu bakış açısıyla öğretim programında değerler arasında yer alan barış kavramı, anahtar yeterliliklerden olan "Sosyal ve Vatandaşlıkla İlgili Yetkinlikler" altında yer alan, "çatışma ve sorun çözme, hoşgörü-tolerans gösterme, farklı bakış açılarını anlama, yapıcı iletişim, arabuluculuk yapma, stres ve öfkeyle başa çıkma, önyargı ve kalıp yargının üstesinden gelme ve müzakere ve uzlaşma” gibi yetkinlik ifadeleri ile ilişkili bulunmuştur.

Dürüstlük değeri ise, "Sosyal ve Vatandaşlıkla İlgili Yetkinlikler" de yer alan “dürüst ve güvenilir olma” ifadesi ile ilişkilendirilmiştir.

Sayg1, "Sosyal ve Vatandaşlıkla İlgili Yetkinlikler" altında "insan haklarına saygı" ve "farklılıklara saygı" boyutlarıyla yer almıştır.

Programda "Kültürel Farkındalık ve İfade Yetkinliği” alanına ait "duyarlılık", "estetik" ve "saygı" olmak üzere 3 değer bulunmaktadır. Bu değerler, Türkiye Yeterlilikler Çerçevesinde yer alan anahtar yetkinlik alanları ile şu şekilde ilişkilendirilmişlerdir.

Programda "Duyarlılık" olarak yer almış olan değer ifadesi, anahtar yetkinlik alanları içerisinde sadece "Kültürel Farkındalık ve İfade Yetkinliği”" altında "kültürel mirasa duyarlılık" boyutuyla mevcuttur. "Saygı" değeri "kültürel çeşitliliğe saygı" ile "kültüre ve sanata saygı" boyutları ile bu yetkinlik alanı altında yer alırken "estetik" değeri "Kültürel Farkındalık ve İfade Yetkinliğgi” içeriğinde görünmektedir.

Ayrıca Programda "Matematiksel Yetkinlik ve Bilim Teknolojide Temel Yetkinlikler"e uygun 2 değer bulunmaktadır. Bu değerler "bilimsellik" ve "sorumluluk" tur.

Bilimsellik, "Matematiksel Yetkinlik ve Bilim Teknolojide Temel Yetkinlikler" altında yer alan "bilimsel bakış açısı" ifadesine uygun bulunmuştur.

Sorumluluk değeri "Matematiksel Yetkinlik ve Bilim Teknolojide Temel Yetkinlikler" altında "Bilim ve teknolojideki gelişme konusunda sorumluluk alma" ifadesi ile yer almıştır.

Çalışkanlık, “Öğrenmeyi Öğrenme” alanına uygun bulunan tek değerdir. 2017 Sosyal Bilgiler Dersi Öğretim Programının değerleri arasında yer alan çalışkanlık, "Öğrenmeyi Öğrenme” anahtar yetkinlik alanı altındaki "öğrenme konusunda istekli ve ısrarcı olma", "öğrenme sürecindeki zorluklarla başa çıkma" ve "motivasyon" ifadeleriyle ilişkilendirilmiştir.

Programın değerleri arasında yer alan "estetik", “Anadilde İletişim” yetkinlik alanı içeriğinde de yer almaktadır. 
Programda "Dijital Yetkinlik" alanına uygun değer ifadesi yer almamıştır. Ancak Tablo 1' de de görüldüğü gibi taranan ilgili kaynaklara göre "Dijital Yetkinlik" alanı altında değer olarak kabul edilebilecek bir yetkinlik yer almamaktadır.

"İnisiyatif Alma ve Girişimcilik Yetkinliği” altında yer verilen "etik değerlerin farkında olma" şeklinde ifade edilmiş olan “etik" değeri ise Programda yer almamıştır.

2017 SBDÖP'nda sıralanan 18 değer arasında ayrıca "aile birliğine önem verme, bağımsızlık, özgürlük, sevgi, tasarruf, vatanseverlik, yardımseverlik" değerlerine de yer verilmiştir. $\mathrm{Bu}$ değerler TYÇ'de tanımlanmış anahtar yetkiliklerin içeriği ile yakın ilişkili bulunmamıştır. Diğer bir deyişle 11 değer, anahtar yetkinlik alanları ile ilişkili, 7 değer ise programın önemsediği ve anahtar yetkinliklere ek olarak yer verdiği değerlerdir.

\section{Sonuç ve Tartışma}

Araştırmanın TYÇ' de yer alan anahtar yetkinliklerin içerdiği beceri ve değerler açısından analizi sonucunda anahtar yetkinlik alanlarının, konuya ilişkin temel kaynaklardan biri olan Avrupa Komisyonunun "Key Competences For Lifelong Learning, European Reference Framework" başlıklı dokümanda da tanımlandığı gibi (EC, 2007,s. 3) beceri ve değerlerin bir bileşimi olduğu görülmüştür.

2017 SBDÖP'nda anahtar yetkinlikler dışında programda hedeflenen ve çoğunlukla anahtar yetkinlik alanlarının içerdiği becerileri de kapsayan, 26 beceriden oluşan, ek bir beceri listesine yer verilmiştir. $\mathrm{Bu}$ becerilerden 22'si anahtar yetkinliklerle yakın ilişkili bulunmuştur. Benzer bir durum değerler için de söz konusudur. Anahtar yetkinlik alanları, programda 18 değerden oluşan listedeki değerlerin 11'ini içermektedir. Öğretim programında anahtar yetkinlikler ile öğretim programı aracılığıyla kazandırılması hedeflenen beceri ve değerleri kapsayan ortak bir çerçeve oluşturulmamış olması programın yapısal bütünlüğünün anlaşılmasını zorlaştırmaktadır.

Anahtar yetkinlik alanları içerdikleri beceri ve değerler açısından analiz edildiğinde 8 anahtar yetkinlik alanı içinde en fazla $(f=28)$ ifade ile tanımlanması sebebiyle en geniş kapsamlı yetkinlik alanının "Sosyal ve Vatandaşlıkla İlgili Yetkinlikler" olduğu söylenebilir. Bu yetkinlik alanını "Matematiksel Yetkinlik ve Bilim Teknolojide Temel Yetkinlikler" $(f=17)$ ve "İnisiyatif Alma ve Girişimcilik" yetkinliği $(f=16)$ takip etmektedir. "Öğrenmeyi Öğrenme" yetkinlik alanı altında 11, "Kültürel Farkındalık ve İfade" yetkinliği altında ise 9 ifade yer almıştır. Ayrıca "Yabancı Dillerde İletişim" ve "Dijital Yetkinlik" alanları 8'er ifade ile tanımlanırken, "Anadilde İletişim” yetkinlik alanına ait 7 ifadeye yer verilmiştir. Kaynaklarda en az ifadeyle tanımlanan yetkinlik alanı "Anadilde İletişim" dir.

Diğer amaç doğrultusunda 2017 SBDÖP'nda yer alan temel beceri ve değerlerin, TYÇ’deki anahtar yetkinlik alanları ile ilişkisi analiz edilmiştir. 2017 SBDÖP'nda, anahtar yetkinlik alanları içinde en fazla $(f=9)$ "Matematiksel Yetkinlik ve Bilim Teknolojide Temel Yetkinlikler"e ait becerilere yer verilmiş olduğu sonucuna ulaşılmıştır.

2017 SBDÖP’nda “... Sosyal Bilgiler Dersi Öğretim Programı başta sosyal ve vatandaşlıkla ilgili yetkinlikler alanı olmak üzere diğer yetkinlik alanlarının becerileriyle de güçlü ilişkiler içindedir (MEB, 2017,s. 8)." ifadesi ile diğerlerine göre 
daha güçlü ilişkiler içinde olunan yetkinlik alanının "Sosyal ve Vatandaşlıkla İlgili Yetkinlikler” olduğu belirtilmiştir. 2018 SBDÖP'nda bu ifadeye yer verilmemiştir. Araştırma sonuçları doğrultusunda "Öğretim Programında Temel Beceriler" boyutunda en yüksek frekansın "Matematiksel Yetkinlik ve Bilim Teknolojide Temel Yetkinlikler" alanına ait olduğu görülmüştür. Bu durum Barr, Barth ve Shermis'in (1977) ortaya koyduğu ve daha önce 2005 SBDÖP ile vurgulanan "sosyal bilimler olarak sosyal bilgiler” geleneğinin (MEB, 2005, s. 51) de “beceriler boyutu” ile 2017 SBDÖP'na da yansımış olduğunu göstermektedir.

Programda temel beceriler yönüyle en fazla $(f=8)$ yer alan ikinci anahtar yetkinlik alanı ise "Sosyal ve Vatandaşlıkla İlgili Yetkinlikler" dir. Programda bu alana ait olarak sıralanan beceriler; empati, iletişim, kalıp yargı ve önyargıyı fark etme, karar verme, öz denetim, politik okuryazarlık, problem çözme ve sosyal katılımdır. "Sosyal ve Vatandaşlıkla İlgili Yetkinlikler" den olan "sağlıklı yaşam" ve "toplumsal değişime uyum" ise 2017 SBDÖP becerileri arasında yer almamaktadır. "Sağlıklı yaşam" ile "toplumsal değişime uyum" u da kapsayan "esneklik ve uyum” becerisinin 21. Yüzy1l becerilerini çalışan P21 (Partnership for 21st century skills, 2006) ve ATCS (Griffin, McGaw, \& Care, 2012) gibi kaynaklarda da 21. Yüzyıl becerileri arasında yer aldı̆̆ görülmektedir (Ekici, Abide, Canbolat \& Öztürk, 2017).

Programda "İnisiyatif Alma ve Girişimcilik Yetkinliği” alanına uygun 6 beceriye yer verilmiştir. Bunlar; finansal okuryazarlık, girişimcilik, iletişim, iş birliği, karar verme ve yenilikçi düşünmedir. Ancak "İnisiyatif Alma ve Girişimcilik Yetkinliği” alanının gerektirdiği "liderlik", "proje yönetme" gibi becerilerin öğretim programında yer almadığı görülmüştür. $\mathrm{Bu}$ becerilere, TYÇ’de geçen anahtar yetkinliklere referans gösterilen EU (European Parliament and the Council of the European Union, 2006) kaynağı da dahil olmak üzere 21. Yüzyıl becerileri hakkında çalışan P21 (Partnershipfor 21st century skills, 2006) ve ATCS (Griffin ve diğerleri, 2012) gibi kaynaklarda da rastlamaktayız (Ekici ve diğerleri, 2017).

Programın becerileri arasında "Dijital Yetkinlik" alanına uygun 3, "Anadilde İletişim” yetkinlik alanına uygun 2 beceri yer alırken "Öğrenmeyi Öğrenme” yetkinlik alanına ait 1 beceriye yer verilmiştir. "Anadilde İletişim" yetkinlik alanı programda "Türkçeyi doğru, güzel ve etkili kullanma" ile "iletişim" olmak üzere oldukça kapsamlı iki beceri ile yer almıştır. Aynı şekilde "Dijital Yetkinlik" alanı da programda; "dijital okuryazarlık" olarak başlı başına bir beceri olarak ele alınmıştır. Ayrıca "sosyal katılım" ve "iletişim" de "Dijital Yetkinlik" alanına ait, programda yer verilen diğer becerilerdir.

Programdaki beceriler arasında "Öğrenmeyi Öğrenme" yetkinlik alanına uygun bulunan sadece "araştırma” becerisidir. Bu nedenle 2017 SBDÖP'nın temel beceriler boyutu ile "kendi öğrenme yollarının farkında olma ve öğrenme sürecini yönetme" gibi üst biliş becerilerini (Doğanay, 1997) yeteri kadar desteklemediği söylenebilir. Ayrıca “Öğrenmeyi Öğrenme” yetkinliklerinden olan "etkili zaman ve bilgi yönetimi” de 2017 SBDÖP'nın temel becerileri arasında yer almamıştır. "Zaman yönetimi” ve "bilgi okuryazarlığı" olarak ayrı ayrı da ifade edilebilen bu beceriler, TYÇ'de geçen anahtar yetkinliklere referans gösterilen EU (European Parliament and the Council of the European Union, 2006) kaynağı da dahil olmak üzere 21. Yüzyıl becerileri hakkında çalışan P21 (Partnership for 21st century skills, 2006), ATCS (Griffin ve diğerleri, 2012) ve AASA (American Assosciation of Scholl Administrators, 1996) kaynaklarında da önemsenmektedir (Ekici ve diğerleri, 2017). 
Programın "Öğretim Programında Temel Beceriler" başlı̆̆ altında önce 8 yetkinlik alanı sırasıyla açıklanmış daha sonra sadece "Sosyal ve Vatandaşlıkla İlgili Yetkinlikler”, "İnisiyatif Alma ve Girişimcilik”, "Kültürel Farkındalık ve İfade”, Dijital Yetkinlik" alanlarının içerdiği becerilere yönelik ek bir açıklama yapılmıştır (MEB, 2017: 8). Sadece bu 4 yetkinlik alanının içerdiği becerilere dair ek bir açıklama yapılmış olması, programda bu yetkinlik alanlarının diğerlerinden daha fazla yer almasının planlandığını düşündürmektedir. Bu açıdan bakıldığında "Matematiksel Yetkinlik ve Bilim Teknolojide Temel Yetkinlikler"e ait becerilerin programda planlanandan daha fazla yer aldı̆̆ı söylenebilir.

Öte yandan bu 4 yetkinlik alanı arasında yer almış olmasına rağmen, SBDÖP'nda "Kültürel Farkındalık ve İfade" yetkinliğine uygun herhangi bir beceri mevcut değildir. Örneğin, "görüş, deneyim ve duygularını, sanat ya da kitle iletişim araçları aracılığıyla ifade etme" yetkinliğinin gereği olan "sanatsal ifade" becerisi olmadan bu alana ilişkin yetkinliklerin Sosyal Bilgiler Dersi aracılığı ile destekleniyor olduğunu söylemek gerçekçi olmayacaktır. Programda güçlü ilişki kurulduğu belirtilen ve ek bir açıklamaya gerek duyulan yetkinlik alanları içerisinde yer alması nedeniyle "Kültürel Farkındalık ve İfade" yetkinliğinin planlama aşamasında önemsendiği ve mevcut durumun aksine programda daha ağırlıklı yer almasının beklendiği düşünülmektedir. 2018 SBDÖP'da bu 4 yetkinlik alanına dair yapılan ek açıklama çıkarılmış, programda daha fazla önemsenmiş olduklarına dair araştırma bulgularıyla da örtüşmeyen bu izlenim ortadan kaldırılmıştır.

TYÇ'nde geçen anahtar yetkinliklere referans gösterilen "Hayat Boyu Öğrenme için Anahtar Yetkinlikler Hakkındaki Avrupa Parlamentosu ve Konseyinin Tavsiyesi” nde "Kültürel Farkındalık ve İfade" yetkinliği şu şekilde tanımlanmıştır: "Düşüncelerin, deneyimlerin ve duyguların müzik, performans sanatları, edebiyat ve görsel sanatlar gibi iletişim araçları yoluyla yaratıcı bir şekilde ifade edilmesinin önemini takdir eder" (EC, 2006/962,s.18). Bu tanım TYÇ' nde de EC, 2006 kaynağına referans yapılarak 'Müzik, sahne sanatları, edebiyat ve görsel sanatlar da dahil olmak üzere çeşitli kitle iletişim araçları kullanarak görüş, deneyim ve duyguların yaratıcı bir şekilde ifade edilmesinin öneminin takdir edilmesi” (MYK, 2015,s.28) şeklinde çevrilmiştir.

2017 SBDÖP'nda ise bu yetkinlik alanı ile ilgili esas alınan beceriler şu şekilde açıklanmıştır:

Kültürel farkındalık ve ifade yetkinliği; kişinin doğuştan gelen kapasitesini kullanarak medya yoluyla bireysel ifade kadar sanat ve performans çalışmalarına da değer verip keyif almasını içerir. $\mathrm{Bu}$ beceriler aynı zamanda kültürel faaliyetlerde sosyal ve ekonomik firsatların farkındalığını, kişinin kendi yenilikçi yönünü ve diğerlerinin bakış açısını ifade etmeyi kapsar (MEB, 2017,s.8).

Bu açıklamada “...kişinin kendi yenilikçi yönünü ve diğerlerinin bakış açısını ifade etmeyi..." ifadesi, referans alınan EC, 2006 kaynağında “... the ability torelate one's own creative and expressive points of view to the opinions of others" "kişinin kendi yaratıcı ve dışavurumcu bakış açılarını başkalarının düşünceleriyle ilişkilendirme yeteneğì" şeklinde geçmektedir. Programda yapılan çeviride "creative" kavramı için "yenilikçi" ifadesi kullanılmıştır.

2018 SBDÖP' nda bu paragraf kaldırılmış ancak 2017 SBDÖP'nda da olduğu gibi “yaratıcılık” becerisi 2018 SBDÖP'nda da yer almamıştır. Gerek TYÇ gerek 
program içeriğindeki açıklama incelendiğinde "Kültürel Farkındalık ve İfade” yetkinlik alanının yaratıcılık becerisinden yoksun açıklanamayacağı düşünülmektedir.

Yaratıcılık ve yenilik kavramları arasında belirgin farklılıklar mevcuttur. Yaratıcılık konusunda birçok araştırma ve çalışmasıyla tanınan Amabile (1996), yaratıcılık ve yenilik kavramlarını birbirinden ayırarak şu şekilde tanımlamıştır: Yaratıcılık her alanda yeni ve yararlı bilgilerin üretilmesi şeklinde tanımlanabilirken, yenilik örgüt içindeki bu yaratıcı fikirlerin başarılı bir şekilde uygulamaya konulması şeklinde tanımlanabilmektedir. Bu tanımdan da anlaşılacağı üzere yaratıcılık yeniliğin başlangıç noktası durumundadır (Amabile ve diğerleri, 1996,s. 1155; aktaran, Duran \& Saraçoğlu, 2009,s.16).

Dolayısıyla 2017 SBDÖP'nda yer alan yenilikçi düşünme becerisinin anahtar yetkinliklerden "İnisiyatif Alma ve Girişimcilik" alanının gerektirdiği "yaratıcılık ve yenilik" becerisini, "Kültürel Farkındalık ve İfade" yetkinlik alanının gerektirdiği "yaratıcılık" becerisini ve "Anadilde İletişim" alanı altında yer alan "bağlama uygun ve yaratıcı dilsel etkileşim" yetkinliğini karşılamadığı ve Programın temel becerilerinin bu anlamda eksik kaldığı söylenebilir.

Tay (2017), 2005 ve 2017 Sosyal Bilgiler Dersi Taslak Öğretim Programlarını karşılaştırdığı çalışmasında 2005 programında yer alan yaratıcı düşünme becerisinin taslak öğretim programda yenilikçi düşünme ile verilmeye çalışıldığını belirtmiş ancak kaynaklara dayalı olarak iki kavramın farklı anlamlar içerdiğini açıklamıştır.

2017 SBDÖP'nda “Temel Beceriler” başlığı altında sıralanan beceriler arasında olan ancak anahtar yetkinlik alanlarının içeriği ile yakın ilişkili bulunmayan 4 beceri ise; çevre okuryazarlığg, değişim ve sürekliliği algılama, medya okuryazarlığ 1 ile zaman ve kronolojiyi algılamadır. Bu becerilerden çevre okuryazarlığı, literatürde Roth (1992) tarafından çevre sistemlerinin sağlığını algılama ve yorumlama kapasitesi ve bu sistemlerin sağlığını geliştirmek, yenilemek ve sürdürmek amacıyla uygun davranışlar göstermek olarak tanımlamaktadır. Çevre okuryazarlığı, 21. Yüzyıl becerileri hakkında çalışan kaynaklardan olan, P21 (Partnershipfor 21st Century Learning, 2007) ve OECD (Organization for Economic Co-Operationand Development, 2009)' da 'doğa okuryazarlığı" ifadesiyle yer almaktadır (Ekici ve diğerleri, 2017).

2017 SBDÖP'nda, temel beceriler arasında yer alan “değişim ve sürekliliği algilama" ile "zaman ve kronolojiyi algilama" becerileri ise ilk kez 2005 SBDÖP'nda açıklanan beceriler arasında yer almıştır. Sosyal Bilgiler Dersi (4-5. Sınıflar) Öğretim Programı ve Kılavuzu'nda değişim ve sürekliliği algılama becerisi; benzerlik ve farklılıkları anlama ile tarihsel problemleri kavrayarak alternatif çözümler bulma çerçevesinde açıklanmıştır. Zaman ve kronolojiyi algılama becerisi ise takvim bilgisi temelinde zaman şeritleri oluşturma ve kullanma alt becerileri ile ele alınmıştır(MEB, 2006, s. 30):

2017 SBDÖP “temel beceriler” içerisinde yer alan ancak TYÇ’deki anahtar yetkinlik alanları ile yakın ilişkili bulunmayan becerilerden birisi de "medya okuryazarlığı" dır. Ülkemizde medya okuryazarlığının öğrencilerin eğitimindeki önemini vurgulayan ve ilköğretim ders programında medya okuryazarlığ 1 dersinin okutulması projesini hazırlayan Radyo ve Televizyon Üst Kurulu (2007) ise medya okuryazarlığını "yazılı ve yazılı olmayan, büyük çeşitlilik gösteren formatlardaki (televizyon, video, sinema, reklâmlar, internet vs) mesajlara ulaşma, bunları 
çözümleme, değerlendirme ve iletme yeteneği kazanabilmek" olarak tanımlamaktadır. Medya okuryazarlığı, 21. Yüzyıl becerileri hakkında çalışan kaynaklardan olan OECD (Organization for Economic Cooperation and Development, 2009); P21 (Partnership for 21st century skills, 2006); ATCS (Griffin ve diğerleri, 2012) gibi kaynaklarda yer almaktadır (Ekici ve diğerleri, 2017). Ayrıca Koçoğlu ve Aydın (2017) medya okuryazarlığı becerisinin 2017 SBDÖP'nda yer almasını niteliksel bir gelişimin göstergesi olarak ifade etmişlerdir. Tay (2017) ise çalışmasında "2017 programına medya okuryazarlığ becerisinin eklenmesi etkili vatandaş yetiştirme amacındaki sosyal bilgilerin 2005 programındaki bu anlamdaki sınırlılığını ve eksikliğini giderebileceğini belirterek bu becerinin önemine değinmiştir.

2017 SBDÖP'nda “Değerler Eğitimi” başlığı altında sıralanan 18 değerden 11'i TYÇ'de yer alan anahtar yetkinlikler ile yakın ilişkili bulunmuştur. Programda anahtar yetkinlik alanlarından en fazla $(f=7)$ "Sosyal ve Vatandaşlıkla İlgili Yetkinlikler" e ait değerlere yer verilmiştir. Bu değerler; adalet, barış, dayanışma, dürüstlük, eşitlik, sayg1 ve sorumluluktur.

2017 SBDÖP'nın temel becerileri boyutunda “Kültürel Farkındalık ve İfade Yetkinliği” ne ait becerilere yer verilmemişken programın değerleri arasında bu alana uygun iki değer yer almıştır. Bunlar, kültürel mirasa duyarlılık yönüyle "duyarlılık" ve "estetik" değerleridir.

Öğretim programında "saygı", "sevgi” ve "duyarlılık" değerleri genel ifadeleriyle yer almıştır. Neye saygı duyulup neye duyarlılık geliştirileceğini değerler listesinde açık bir şekilde ifade etmek yerine programda "Değerler kazanımlarla ilişkilendirilirken alt boyutlarıyla ele alınabileceği (Örneğin; sayg1 değerinin farklılıklara saygı, duyarlılık değerinin doğal çevreye duyarlılık ve kültürel mirasa duyarlılık olarak ele alınabileceği gibi) gözden kaçırılmamalıdır.” (MEB, 2017,s. 9) açıklamasına yer verilmesi yoluna gidilmiştir. Eğitim Reformu Girişimi (2017), taslak öğretim programları inceleme ve değerlendirme raporunda estetik değerini örnek göstererek programlardaki bazı değerlerin geniş bir çerçevede yorumlanıp anlaşılabileceğini belirtmiştir. Raporda değerlerin tanımlanması, çocuğun ya da gencin gelişimine uygun şekilde programlarda yer alması ve uygulamada ortak bir standart oluşturulması ileriye dönük önemli adımlar olarak önerilmektedir. Boğaziçi Üniversitesi Eğitim Fakültesi (2017) de taslak öğretim programları ile ilgili görüşlerini içeren raporunda öğretim programlarında tam olarak hangi değerlerden söz edildiği ve/veya o değerlerin isimleri dişında neyi ifade ettikleri net olarak belirtilmesi gerektiğini vurgulamıştır. Ayrıca "Kültürel Farkındalık ve İfade Yetkinliğì" alanı altında geçen ifadelerden birisi de "duygu, düşünce ve deneyimlerini sanat aracılığgyla ifade etmenin önemini takdir etme" dir. TYÇ, anahtar yetkinlikleri içeriğinde yer alması nedeniyle bu tutumun SBDÖP'nda "kültüre ve sanata saygı" gibi değerler ile desteklenmesinin uygun ve gerekli olduğu düşünülmektedir.

2017 SBDÖP'nda sıralanmış olan değerler ile anahtar yetkinlikler ilişkilendirildiğinde programda eksikliği fark edilen bir diğer değer ise "etik" olmuştur. $\mathrm{Bu}$ değer anahtar yetkinlik alanlarının içeriğini ortaya koyan Tablo 1'de "İnisiyatif Alma ve Girişimcilik Yetkinliği” altında "etik değerlerin farkında olma” ifadesi olarak yer almıştır. Etik, TYÇ’de geçen anahtar yetkinliklere referans gösterilen EU (European Parliament and the Council of the European Union, 2006) kaynağının yanı sıra, 21. yüzyıl becerileri hakkında çalışan diğer kaynaklardan olan, AACU (Association of 
American Collages and Universities, 2016) ve ISTE (Internetional Society for Tecnology in Education, 2016) gibi bazı kaynaklarda da önemsenmektedir (Ekici ve diğerleri, 2017).

2017 SBDÖP'nda “Öğretim Programında Değerler Eğitimi” başlığı altında sıralanan değerlerden 7'sinin anahtar yetkinlik alanları ile yakın ilişkili olmadığı sonucuna varılmıştır. Bu değerler "aile birliğine önem verme, bağımsızlık, özgürlük, sevgi, tasarruf, vatanseverlik, yardımseverliktir". Tay ve Yıldırım (2009)'ın Sosyal Bilgiler dersinde kazandırılması amaçlanan değerler konusunda veli görüşlerine yönelik yaptıkları araştırmada da öğrenci velilerinin; vatanseverlik, dürüstlük, aile birliğine önem verme, sorumluluk ve çalışkanlık değerlerini öncelikli gördükleri sonucuna ulaşmışlardır.

Millî Eğitim Temel Kanununda "Türk Milletinin milli, ahlaki, insani, manevi ve kültürel değerlerini benimseyen, koruyan ve geliştiren... yurttaşlar yetiştirmek” ibaresi yer almaktadır. Öğretim programları Anayasa, Millî Eğitim Temel Kanunu gibi düzenleyici üst metinlere uygun olarak tasarlanır (TEDMEM, 2017). TYÇ' de bu düzenleyici üst metinlerden biridir. 2017 SBDÖP üzerinde yapılan bu araştırmanın sonuçları ile TYÇ'de yer alan anahtar yetkinliklerin içeriğinden farklı olarak Programa bazı beceri ve değerler ilave edilmiş, yaratıcılık becerisine ise Programda yer verilmemiş olduğu görülmektedir.

\section{Öneriler}

1. Ulusal yeterlilikler sistemi olarak, TYÇ’de yer alan anahtar yetkinlikler, AYÇ ile uyumunun yanı sıra, öğretim programları ile bireylere kazandırılması hedeflenen diğer beceri ve değerleri de içerecek biçimde yeniden düzenlenebilir. TYÇ'de yer alan anahtar yetkinliklerin ülke olarak ihtiyaçlarımız ve beklentilerimizi karşılayan beceri ve değerlerin tamamını içerdiği düşünüldüğünde anahtar yetkinliklerden tüm öğretim programlarının çatısını oluşturacak biçimde yararlanmak uygun olabilir.

2."Kültürel Farkındalık ve İfade" yetkinlik alanı içeriğine uygun olarak SBDÖP'nın temel becerileri, "sanatsal ifade ve yaratıcılık" becerilerini de içerecek biçimde düzenlenebilir.

3. SBDÖP temel becerileri "Öğrenmeyi Öğrenme” yetkinlik alanının içeriği doğrultusunda "öğrenme sürecini yönetme, etkili zaman ve bilgi yönetimi” gibi becerileri de destekleyecek biçimde zenginleștirilebilir.

4. SBDÖP becerileri arasında "sağlıklı yaşam" ve "toplumsal değişime uyum" u da kapsayan "esneklik ve uyum", liderlik" ve "proje yönetme" becerileri yer alabilir.

5. SBDÖP'nda saygı, sevgi, duyarlılık gibi bazı değerlerin; kültüre ve sanata sayg1, farklılıklara sayg1, doğal çevreye duyarlılık ya da kültürel mirasa duyarlılık şeklinde açık bir şekilde ifade edilmesi öğretim programı ile bireylerden beklenenleri daha açık bir şekilde ortaya koyacaktır. Değerlerin açık ifade edilmesi, öğretim programında "sevgi" değerinin yanı sıra "yardımseverlik" ve "vatanseverlik" gibi değerlerin de verilmesi ile oluşan tekrara düşme durumunu da engelleyebilir.

6. Bu çalışmada TYÇ’de yer alan anahtar yetkinliklerin SBDÖP’nın “Öğretim Programında Temel Beceriler" ve "Öğretim Programında Değerler Eğitimi” boyutları ile ilişsisine bakılmıştır. Sosyal Bilgiler ya da diğer derslerin öğretim programları da bütün boyutları ile anahtar yetkinliklerle olan ilişkisi açısından incelenebilir. 


\section{Summary}

Purpose and Significance: Social Studies Curriculum (SSC) was updated based on Turkey Qualifications Framework (TQF) in 2017 by Turkish Ministry of Education. TQF states that each individual is expected to win 8 key competencies and that key competencies must be included in education and training programs

The content of each key competency domain is defined in the European Qualifications Framework and the Turkey Qualifications Framework which is stated to be prepared in accordance with it.

This study was prepared for the following two main purposes:

1. Analyzing the skills, attitudes and values of the key competencies mentioned in the TQF

2. Comparison of the contents of the "Basic Skills in Curriculum" and "Teaching Values in Curriculum" dimensions of the 2017 SSC and the content of key competency areas in the TQF.

Methods: In this study, case studies were used within the qualitative research model. In line with the objectives of the research, the descriptions of the key competencies in the TQF were analyzed and the skills, attitudes and values were determined. One of the sources used in the analysis was the explanations for key competences in "Turkey Qualifications Framework" which is published in the Official Gazette dated 02.01.2016 and numbered 29581.

Also, Key Competencies for Lifelong Learning-European Reference Framework, which is included in the Recommendation of the European Parliament and the Council of Europe on "Key Competences for Lifelong Learning" is the second resource used in the analysis. A table of criteria was established in the analysis of the data obtained from the analysis of the two sources and the dimensions of "Basic Skills in Curriculum" and "Teaching Values in Curriculum" of 2017 SSC. Then, the skills, attitudes and values contained in the key competence fields were compared with the 26 skills and 18 values listed in the "Basic Skills in Curriculum" and "Teaching Values in the Curriculum" of the 2017 SSC.

The sources used to construct the table of criteria showing the skills, attitudes and values contained in the key competency areas and the dimensions of "Basic Skills in Curriculum" and "Teaching Values in Curriculum" of the 2017 SSC were examined through content analysis. After the research data were separately coded by two researchers, the tables were finalized. The consistency of the explanations that researchers use independently of each other is determined by marking them as "Union of Opinion" or "Difference of Opinion". The same areas of competence is appropriate for the same statements in the documents are considered as union of opinion, and those where different areas of competence are appropriate are considered as "Difference of Opinion". In the case of contradictions by both researchers, the other researcher's opinion was used. The average cohesion value among experts was found $93 \%$ for the analysis of key competence areas in the TQF; $92 \%$ for the distribution of the basic skills of the 2017 SSC to key competence areas; $85 \%$ for distribution of the values of 2017 SSC to key competences. 
Results: As a result of analyzing the sources identifying the key competencies, appropriate skills, attitudes, or values are grouped into each key competency area. Accordingly, the most expressions were placed under the heading "Social and Civic Competences". For this reason, it can be said that the most comprehensive competence field among key competencies is "Social and Citizenship Competencies". The competence area defined by the least words in the sources is "Communication in Mother Tongue".

Among the key areas of competence in 2017 SSC, the skills of "Mathematical Competence and Basic Competencies in Science Technology" are mostly mentioned. The second key competence area that takes the most place in the skills of the program is "Social and Civic Competences". The program did not include any skills related to "Cultural Awareness and Expression Competence" while there were 6 skills related to "Sense of Initiative and Entrepreneurship". Also 4 skills that are not closely related to the content of any key competencies are included. These skills are; environmental literacy, perception of change and continuity, media literacy, time and chronology.

When looking at the results in terms of values, it is seen that the program has the most related values in the field of "Social and Civic Competences". Among the 18 values listed in the 2017 SSC, "values of family unity, independence, freedom, love, saving, patriotism, benevolence" were also included. These values were not related to the content of key competences.

Discussion and Conclusions: According to findings, "Mathematical Competence and Basic Competences in Science and Technology" is the most relevant area with the key competences in the "Basic Skills in Curriculum" dimension. However, it is stated in the curriculum that "Social and Civic Competencies" is at the forefront of the areas where strong relations are established. "The healthy life" and the "social change adaptation "skills listed below "Social and Civic Competencies" are not among the skills of the 2017 SSC. The program has 6 competitions suitable for "Sense of Initiative and Entrepreneurship" field. However, skills such as leadership and project management, have not been included in the curriculum. Moreover, it can be said that 2017 SSC does not support mental cognitive skills such as "being aware of their own learning paths and managing the learning process" in the "Learning to Learn" competence of the "Basic Skills in Curriculum" dimension. Among the basic skills of the curriculum "artistic expression and creativity" skills were not included. However, it is thought that the field of "Cultural Awareness and Expression" competence cannot be explained without these skills. It can be said that it would be better to include these values in SSC, which are seen to be incomplete when compared with the contents of key competence fields. On the other hand, it is expected that the key competencies and content contained in the TQF as a framework of national qualifications should include all targeted skills, values and attitudes towards teaching with the curriculum. In this case, key competencies can be reflected in all to curriculum without adding or subtracting. 


\section{Kaynakça}

Aktaş, Ö. \& Safran, M. (2013). Evrensel bir değer olarak barış ve barış eğitiminin tarihçesi. Türkiye Sosyal Araştırmalar Dergisi, 17(2), 131-150.

American Assosciation of Scholl Administrators [AASA]. (1996). Assessment and teaching of 21st century skills. Retrieved from https://www.aasa.org/content.aspx?id=1320

Griffin, P., McGaw, B., \& Care, E. (2012). Assessment and teaching of 21st century skills. Dordrecht: Springer.

Association of American Colleges and Universities [AACU]. (2007). College learning for the new global century. Washington DC: AACU. Retrieved from https://www.aacu.org/sites/default/files/files/LEAP/GlobalCenturyfinal.pdf

Bednarz, S. W. (2001). Thinking spatially: Incorporating GIS in preand post secondary education. Retrieved from http://www.geography.org.uk/download/ EVbednarzthink.doc

Boğaziçi Üniversitesi (2017). Eğitim fakültesi 2017 taslak ögretim programları ile ilgili görüşleri. "http://www.fed.boun.edu.tr/form_files/ Mufredat_degisikligi_fakulte_gorusleri_2017.pdf adresinden alınmıştır.”

Cohen, L., \& Manion, L. (1997). Research methods in education. London: Routledge.

Creswell, J. W. (1998). Qualitative inquiry and research design: choosing among five traditions. Thousand Oaks, CA: Sage Publications.

Çakmak, Z., Kaçar, T., \& Arıkan İ. (2017). Sosyal bilgiler öğretmenlerinin ortaokul sosyal bilgiler dersi taslak öğretim programına ilişkin görüşleri. The Journal of Academic Social Science, 5(54), 576-597.

Doğanay, A. (1997). Ders dinleme sırasında bilişsel farkındalık ile ilgili bilgilerin kullanımı. Çukurova Üniversitesi Ë̆itim Fakültesi Dergisi, 2(15), 34-42

Doğanay, A., Çuhadar, A., \& Sarı, M. (2007). Öğretmen adaylarının siyasal katılımcılık düzeylerine çeşitli etmenlerin etkisinin demokratik vatandaşlık eğitimi bağlamında incelenmesi. Kuram ve Uygulamada Ĕ̈itim Yönetimi, 50(50), 213-246.

Duran, C. \& Saraçoğlu, M. (2009) Yeniliğin yaratıcılıkla olan ilişkisi ve yeniliği geliştirme süreci. Yönetim ve Ekonomi, 16(1), 7-71.

Eğitim Reformu Girişimi (ERG) (2017). Öğretim programları arka plan raporu

http://www.egitimreformugirisimi.org/egitim-izleme-raporu-2016-17/ adresinden alınmıştır.

Eğitim Sen (2017). Ĕgitim müfredatı değişiklikleri ve taslak ögretim programları raporu. http://egitimsen.org.tr/wp-content/uploads/2017/02/M\%C3\%BCfredatRaporu.pdf adresinden alınmıştır.

Eğitim-İş. (2017). Taslak öğretim programlarl değerlendirme raporu. http://www.egitimis.org.tr/guncel/sendika-haberleri/egitim-ve-bilim-isgorenlerisendikasi-taslak-mufredat-raporu-2275/\#.WjIlkUpl_IU adresinden alınmıştır.

Ekici, G., Abide Ö. F., Canpolat, Y., \& Öztürk A. (2017). 21.yüzyıl becerilerine ait veri kaynaklarının analizi. Ĕgitim ve Öğretim Araştırmaları Dergisi, 6(Özel Sayı), 124134 


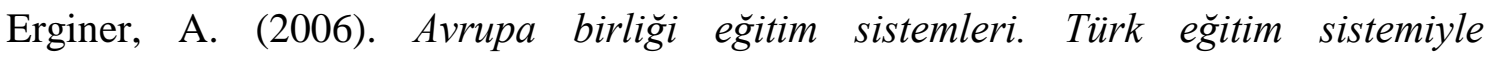
karşılaştırmalar. Ankara: Pegema Yayıncılık.

Gürel, D. (2017). 2017 Taslak sosyal bilgiler öğretim programına yönelik yapısal bir değerlendirme. I. Uluslararası Sinırsız Eğitim ve Araştırma Sempozyumu (USEAS2017) Tam Metin Bildiri Kitabı, 236-246.

ISTE (2007). National educational technology standards and performance indicators for students. Oregon: ISTE. OECD countries. OECD Education Working Papers (No. 41). doi:10.1787/218525261154

Koçoğlu, E. \& Aydın M. (2017). Alan uzmanlarına göre 2017 sosyal bilgiler programının 2005 programı çerçevesinde analizi. International Journal of Social Science Research, 6(1), 60-72. ISSN: 2146-8257

Kotluk, N. \& Kocakaya, S. (2015). 21. Yüzyıl becerilerinin gelişiminde dijital öykülemeler: Ortaöğretim öğrencilerinin görüşlerinin incelenmesi. Eğitim ve Öğretim Araştırmaları Dergisi, 4(2), 354-363

McMillan, J. H. (2000). Educational research: Fundamentals for the consumer. New York: Longman.

Merriam, S. (1998). Qualitative research and case study applications in education. San Francisco: Jossey-Bass

Mesleki Yeterlilikler Kurumu (MYK) (2015). Türkiye yeterlilikler çerçevesi. Ankara

Miles, M.B. \& Huberman, A. M. (1994). Qualitative data analysis: An expanded sourcebook (2nd ed.). ThousandOaks, California: SAGE.

Milli Eğitim Bakanlığı (MEB) (2017). Sosyal bilgiler dersi ögretim programı (ilkokul ve ortaokul $4, \quad 5, \quad 6$ ve $7 . \quad$ siniflar). Ankara. http://mufredat.meb.gov.tr/ProgramDetay.aspx?PID=155adresindenalınmıştır.

Milli Eğitim Bakanlığı (MEB) (2018). Sosyal bilgiler dersi ögretim programı (ilkokul ve ortaokul 4, 5, 6 ve $7 . \quad$ sinfflar). Ankara. http://mufredat.meb.gov.tr/ProgramDetay.aspx?PID=354adresinden alınmıştır.

Milli Eğitim Bakanlığı (MEB) (2006). İlköğretim sosyal bilgiler dersi, 6. sinıf ögrretim programı ve kılavuzu. Ankara: Talim ve Terbiye Kurulu Başkanlığı.

Milli Eğitim Bakanlığı (MEB), (2005). Illköğretim sosyal bilgiler dersi 4-5. sinıflar ögretim programı ve kılavuzu. Ankara: Talim ve Terbiye Kurulu Başkanlığı.

National Council on Measurement in Education [NCME] (2016). About NCME. Retrieved from http://www.ncme.org/ncme/NCME/About/NCME/ About1/About1 .aspx?hkey=7548ee94-566a-4475-ba8e-926425043430

OECD (2012). PISA 2012 results: Students and money: Financial literacyskillsforthe 21 st century (Volume VI). PISA, OECD Publishing.

Orta Doğu Teknik Üniversitesi (ODTÜ) (2017). MEB taslak öğretim programlarına ilişkin görüş ve öneriler https://eds.metu.edu.tr/.../meb_taslak_ogretim_programlarina_iliskin_odtu_ebb_gor us... adresinden alınmıştır.

Patton, M. Q. (1990). Qualitative evaluation and research methods (2nd ed.).Newbury Park, CA: Sage 
Roth, Charles E. (1992). Environmental literacy: Its roots, evolution, anddirections in the 1990s. Columbus, OH: ERIC/CSMEE. Retrieved from https://eric.ed.gov/?id=ED348235

RTÜK. (2007). İlköğretim medya okuryazarlı̆̆ dersi ögretmen el kitabı. Ankara: RTÜK

Silverman, D. (2001). Interpreting qualitative data: methods for analysing talk, text and interaction. London: SAGE Publication.

Tay, B. (2017). 2005 Sosyal bilgiler dersi öğretim programı ile 2017 sosyal bilgiler dersi taslak öğretim programının karşılaştırması. International Journal of Eurasia Social Sciences, 8(27), 461-487.

Tay, B. \& Yıldırım, K. (2009). Sosyal bilgiler dersinde kazandırılması amaçlanan değerlere ilişkin veli görüşleri. Kuram ve Uygulamada Eğitim Bilimleri, 9(3), 14991542.

TEDMEM. (2017). Öğretim programı taslaklarında değerler ĕgitimi. https://tedmem.org/etiket/taslak-ogretim-programlari adresinden alınmıştır.

The European Parliament and the Council of the European Union (EC). (2006). Key competences for life long learning - a european reference framework, Retrieved from http://eur-lex.europa.eu/legal-content/EN/TXT/?uri=celex\% 3A32006H0962

The Partnership for 21st Century Learning. (2015). Framework for 21st century learning. The partnership for 21st century learning. Retrieved from http://www.p21.org/storage/documents/docs/P21_Framework_Definitions_New_L ogo_2015.pdf

TTKB. (2017). Millî ĕgitim bakanlı̆g ilköğretim ve ortaöğretim öğretim programlarının güncellenmesi

https://ttkb.meb.gov.tr/meb_iys_dosyalar/2017_01/13152934_basYn_aYklamasY_ 13012017.pdf adresinden alınmıştır.

Tutkun, Ö. F. \& Aksoyalp, Y. (2010). 21. yüzyılda öğretmen yetiştirme eğitim programının boyutları. Selçuk Üniversitesi Sosyal Bilimler Enstitüsü Dergisi, 24, 361-370.

World Economic Forum. (2015). New vision for education: unlocking the potential of technology. Cenevre: World Economic Forum. Retrieved from http://www3.weforum.org/docs/WEFUSA_NewVisionforEducation_Report2015.p df

Yıldırım, A. \& Şimşek, H. (1999). Sosyal bilimlerde nitel araştırma yöntemleri. (1. baskı) Ankara: Seçkin Yayıncılık.

Yıldırım, A. \& Şimşek, H. (2006). Sosyal bilimlerde nitel araştırma yöntemleri. (6. baskı) Ankara: Seçkin Yayıncılık. 